\title{
Şanlıurfa Müzesi'nde Bulunan Artuklu Dönemine Ait Bir Grup Sikke
}

\author{
Dr. Öğr. Üyesi Ercan Çalışa,b
}

Özet

Güneydoğu Anadolu Bölgesi'nin en gelişmiş şehirlerden biri olan Şanlıurfa, kuzeydoğuda Diyarbakır, kuzeybatıda Adıyaman, güneyde Suriye, doğuda Mardin ve batıda Gaziantep illeri ile komşudur. Paleolitik döneme kadar uzanan Şanlıurfa son dönemlerde gerçekleştirilen kazılarla dünya tarihi ve sanatı açısından önemli bir yere sahip olmuştur. Tarihte Şanlıurfa, Mezopotamya olarak adlandırılan bölgenin en eski yerleşim yerlerinin başında gelmektedir. Çağlar boyunca çok sayıda medeniyete ev sahipliği yapmış bölgenin il merkezine yakın bir konumda yer alan Örencik köyünde bulunan Göbekli Tepe'de yapılan kazılar, insanoğluna ait tarih, sanat, sosyal ve kültürel geçmişin yeniden yazılmasına yol açmıştır. Göbekli Tepe'de gün yüzüne çıkarılmış ve araştırmacılar tarafından MÖ. 10.000'li yıllara tarihlendirilen mimari yapılar, mimarlık ve sanat tarihi açısından önemli bir buluş olmuştur. Dolayısıyla böylesine önemli bir bölgede yapılan her çalışmanın değerli olacağı düşüncesiyle, Şanlıurfa Müzesi'nde bulunan Artuklu dönemine ait bir grup sikke tanitılarak, sanat tarihi açısından değerlendirilmiştir.
Anahtar Kelimeler

Güneydoğu

Müze

Artuklu

Sikke

Makale Hakkında

Geliş Tarihi: 03.02.2020

Kabul Tarihi: 08.07.2020

Doi: $10.18026 /$ cbayarsos.684237

\section{A Group of Coins from the Artuqid Period in Şanlıurfa Museum}

\begin{abstract}
Şanlıurfa, one of the most developed cities of the Southeastern Anatolia Region, is adjacent to Diyarbakır in the northeast, Adıyaman in the northwest, Syria in the south, Mardin in the east and Gaziantep in the west. Dating back to the Paleolithic period, Şanlıurfa has gained an important place with the recent excavations in terms of world history and art. In history, Şanlıurfa is one of the oldest settlements of the region, which was called the Mesopotamia. The excavations in Göbekli Tepe, located in the village of Örencik that is close to the city center of the region, which has hosted many civilizations throughout the ages, resulted in the rewriting of the history, art, social and cultural history of the mankind. The architectural structures, which were excavated in Göbekli tepe and dated back to 10000 B.C. by the researchers, have turned out to be important discoveries in terms of architecture and history of art. Therefore, with the idea that all works carried out in such an important region would be valuable, a group of coins belonging to the Artuqid period in the Sanliurfa Museum were introduced and interpreted in terms of art history.
\end{abstract}

Keywords

Southeast

Museum

Artuqid

Coin

\begin{tabular}{r} 
About Article \\
\hline Received: 03.02 .2020 \\
Accepted: 08.07 .2020 \\
Doi: $10.18026 /$ cbayarsos.684237
\end{tabular}

Doi: $10.18026 /$ cbayarsos.684237

a İletişim Yazarı: ercancalis@yyu.edu.tr

b Dr. Öğr. Üyesi, Van Yüzüncü Yıl Üniversitesi, Edebiyat Fakültesi, Sanat Tarihi Bölümü, ORCID: 0000-0003-1359-4533 


\section{Giriş}

Güneydoğu Anadolu Bölgesi'nin en gelişmiş şehirlerden biri olan Şanlıurfa, kuzeydoğuda Diyarbakır, kuzeybatıda Adıyaman, güneyde Suriye, doğuda Mardin ve batıda Gaziantep illeri ile komşudur. Paleolitik döneme kadar uzanan Şanlıurfa son dönemlerde gerçekleştirilen kazılarla dünya tarihi ve sanatı açısından önemli bir yere sahip olmuştur. Tarihte Şanlıurfa, Mezopotamya olarak adlandırılan bölgenin en eski yerleşim yerlerinin başında gelmektedir. Çağlar boyunca çok sayıda medeniyete ev sahipliği yapmış Şanlıurfa Anadolu'nun en eski tarihi kalıntılarına sahiptir. Şanlıurfa il merkezine yakın bir konumda yer alan Örencik köyünde bulunan Göbekli Tepe'de yapılan kazılar, insanoğluna ait tarih, sanat, sosyal ve kültürel geçmişin yeniden yazılmasına yol açmıştır. Göbekli Tepe'de gün yüzüne çıkarılmış ve araştırmacılar tarafından MÖ. 10.000'li yıllara tarihlendirilen mimari yapılar, mimarlık ve sanat tarihi açısından önemli bir buluş olmuştur. Bunların yanı sıra Göbekli Tepe heykel, resim ve plastik sanatlar alanında geçmişin ilk örneklerini sergilemektedir. Elbette ki bölgenin bu denli önemli bir merkez olmasını sağlayan en büyük etkenlerden biri de jeopolitik konumudur. Verimli hilal olarak adlandırılan Fırat ve Dicle nehirlerinin oluşturduğu havzalar içinde yer alan bu yerleşim yerinin ortaya çıkması, Şanlıurfa'nın geleceği açısından belirleyici olmuştur.

Şanlıurfa bölgesinin tarihi, dokusu ve son dönemlerde artan arkeolojik potansiyelinden dolayı, gerek eserlerin hak ettiği şekilde sergilenmesine, gerekse artan turist sayısı dikkate alınarak, çok kompleksli bir müzeye ihtiyaç olduğu gerçeğiyle beraber, günümüzdeki modern müzenin temeli 2012 yılında atıldı. 24 Mayıs 2015 tarihinde hizmete açılan Şanlıurfa Müzesi, 14 ana sergi salonuyla birlikte 33 adet canlandırma alanına sahiptir. 3 katlı olarak yapılan müze, ayrıca insanların bir takım ihtiyaçlarını giderebileceği sosyal alanlara da sahiptir. Ancak müzeyi önemli kılan en önemli husus ise şüphesiz ki dünyanın en eski tapınağı olan Göbekltepe'ye ait eserlerin burada sergilenmiş olmasıdır. Müzedeki yetkililerden alınan bilgilere göre müze koleksiyonunda yaklaşık olarak 65.000 eser bulunmaktadır. Bunlardan 5000 tanesi çeşitli salonlarda sergilenmektedirler. Geriye kalan diğer eserlerin de belli bir plan ve program çerçevesinde aşamalı olarak sergi salonlarında yerini alacakları belirtilmektedir.

Neolitik dönemle birlikte yerleşik yaşama başlayan insanoğlunun hayatında önemli değişiklikler meydana geldi. Bu dönemden önce para ile ilgili herhangi bir düşünce ortaya çıkmamıştı. Beliren ihtiyaçlarını kendileri giderme yoluna gittikleri için insanlarda mal ile ilgili değeri saptama veya değişime tabi tutma düşüncesi yerleşik düzene geçmeyle başlamıştır (Tekin, 1997, s. 13). Yerleşik düzene geçişte özellikle tarımın kontrol altına alınması ve bu alanların suyu bol olan yerlerden seçilmesi de ayrıca önemlidir. Nihayetinde tarımsal alanlardan elde edilecek ürünler ticareti de beraberinde getirdi. Zira Şanlıurfa bölgesinin eski çağlarda verimli sulak tarım alanlarına ev sahipliği yaptığ 1 ve bu durumun bölge ticaretine eskiden beri bir katkı sağladığı bilinmektedir. İlk başlarda başlayan ticaret biçimi değiş - tokuş şeklinde gerçekleşmişti. Başta tahıl ürünleri, hayvanlar ve çeşitli araç gereçler birer ödeme aracıydı. Yakın bir zamana kadar özellikle ülkemizin Güneydoğu Anadolu Bölgesi'nin şehirlerden uzak bazı köy yerleşkelerinde, çok az bir oranda da olsa bu takas usulünün devam edildiğine şahit olunmuştur. Buğday, arpa ve mercimek karşılığında sebze ve meyve gibi ürünler piyasadaki maddi değerleri göz önüne alınarak birbirleriyle takas ettirilmiştir. Aradan geçen binlerce yıllık zamana rağmen aynı koşulların farklı topluluklarda benzer reflekslere yol açtığ 1 gözlemlenmiştir. Madenlerin keşfi ile beraber eski çağlarda yaşanan takas durumu büyük bir çapta değişmeye başlamıştır. Birbirleriyle takas edilen kimi canlı hayvan ve çeşitli eşyalara ait değerinin karşılığını bulmadaki sıkıntılar ile alınıp satılması ve muhafaza 
edilmesinde yaşanan tüm zorluklar, madenleri daha da önemli kılmıştır. Madenler ilk etapta işlenmemiş bir şekilde bu ihtiyacı giderirken, zamanla belli bir standarda erişip sikke olarak daha da işlevsel bir araç haline gelmiştir. Günümüzde değişim aracı olarak bilinen para aynı zamanda bir değer ölçüsüdür. Mal karşılığında farklı malların alınması (trampa/barter) sisteminde, yukarıda anlatılan zorlukların yanı sıra, tarafların ihtiyaç duydukları ürünlerin de birbirlerinde bulunması gerekmekteydi(Tekin, 1997, s. 13-14). Bir ödeme aracı olan sikke ile para arasında da önemli nüans vardır. Her ikisi de temelde birer ödeme aracı olmakla beraber, her sikkenin bir para olduğuna karşın her paranın bir sikke olmadığı gerçeğidir (Tekin, 1997, s. 19). Yukarıda sayılan ve belli amaçlara hizmet etmenin yanı sıra, sikkeler bağımsızlık ve hâkimiyetin de sembolü olmuş ve devlet yöneticilerinin kimliğini taşımıştır.

Yukarıda dile getirilen tarihi sikkelerin serüveninden yola çıkarak, ait oldukları döneme dair birbirinden bağımsız çok farklı bilim dalı için aydınlatılması gereken sorulara yanıt olduğu anlaşılmıştır. Bunun yanı sıra sikke bir sanat eseri olarak düşünüldüğünde, maden işlemeciliğindeki el becerileri ve yeteneklerinin ön plana çıktığı gözlemlenir. Sikkenin yapımında kullanılan malzemenin niteliğinden dolayı, çoğunlukla dövme ve döküm yapım teknikleriyle sikkeler üretilmiştir (Uykur, 2010, s. 2). Ayrıca ortaya çıktığı tarihten beri dünyanın çok farklı bölgelerinde üretilen sikkeler ile günümüzde üretilmeye devam eden madeni paraların genellikle form açısından yuvarlak ve düzgün bir şekle sahip oldukları görülmektedir. İlk başlarda sikkelerin biçimlerinde düzensizlikler olsa da üretimi ilerledikçe yuvarlak bir forma dönüşmeye başladığı kazılarda ortaya çıkarılıp müzelerde sergilenen örneklerden anlaşılmaktadır. Bu durum yuvarlak olarak işletilip basılmalarının üretiminde daha kolay olduğunu göstermektedir.

\section{Artuklular}

Bizans'a karşı Malazgirt Savaşı ile büyük bir başarı elde eden Büyük Selçuklu Sultanı Alparslan, Anadolu topraklarının hızlı bir şekilde Türkleşme sürecine geçmesini başlatmıştır. Bizans'ın dağılmasıyla beraber Türkler Anadolu'ya göç etmeye başlamış ve bölge ilelebet Türk toprakları olacak şekilde yurt edinilmeye başlanmıştır. Bu sırada Anadolu'daki Türk hanedanları bölgenin kaderini belirleme noktasında önemli bir işleve sahipti. Bu hanedanlar birinci dönem Anadolu beylikleri olarak bilinmektedir. Selçuklu sultanını tanıyan ve onun adına ülkeyi yöneten bu hanedanlardan biri de 1102-1408 yıllarında Anadolu'nun Güneydoğusunda hüküm sürmüş olan Artuklular'dır. Artuklular, Hısn-1 Keyfa (Hasankeyf) ve Amid (Diyarbakır) Artukluları, Harput (Elazığ) Artukluları ve Mardin Artukluları şeklinde üç kola ayrılarak, bu şehirlerde merkezi otoritesini kurmuş bir Türkmen hanedanıdır (Uykur, 2017, s. 4-15). İsmini Türkmen beyi olan Artuk Bey'den alan Artuklular, diğer çok sayıdaki Türk sülaleleri gibi Türk kültürü ve sanatı adına iz bıraktığından önemli bir yere sahiptir. Nitekim Anadolu Türk mimarisinin temellerinin atılmasında büyük katkıları olmuştur. Cami ve medrese yapıları Anadolu'da bu dönemde sayı olarak artmaya başlamış ve gelişme göstererek hızlı bir şekilde devam etmiştir (Aslanapa, 2011, s. 135). Diyarbakır, Mardin, Hasankeyf ve Silvan' da çok sayıda Artuklu eseri mevcuttur. Eminüddin Küllüyesi, Hatuniye Medresi ile ünlü Malabadi köprüsü, Artuklular zamanından kalma önemli mimari eserlerden birkaç tanesidir.

Bu çalışmada Şanlıurfa Müzesi'nde bulunan Artuklu dönemine ait bir grup sikke örnekleri üzerinde bezeme ve yazı unsurlarının ayrıntılı bir biçimde çözümlenmesi ve tanımlanması yapılarak, sanat tarihi açısından değerlendirilmiştir. Sikke önceden ağırlığ üzerinde darp edilip tedavüle çıaran ve gerek görüldüğünde geri almayı da taahhüt eden 
hükümdarın veya mevcut yönetimin arma ya da işaretini taşıyan disk formu şeklinde metalden yapılmış bir paradır. (Tekin, 1997, s. 19). Diğer bir ifadeyle sikke bir takım değerli madenlerin el uzluğu ile darp edilerek, belli standart ve forma dönüştürme işlemi olarak da adlandırılabilir. Köken olarak sikke kelimesi Arapça kökenli olmakla beraber "damga veya nakış basmak için hazırlanmış demir kalıp" demektir (Tekin, 2009, s. 179).

Genel itibarıyla sikkeler sanat tarihi biliminin yanı sıra tarih, madencilik ve ekonomi bilimleri yönünden de araştırılması gereken önemli konulardan biridir. Eski metal paraları ve madolyanları inceleyen bilim dalı ise nümizmatik bilimidir. Sikke bilimi anlamına da gelen Nümizmatik, ekonomi tarihine doğrudan ayna tutmaktadır. Bunun yanı sıra Nümizmatik bilimi; Sanat Tarihi, Tarih ve Coğrafya gibi çeşitli sosyal bilim dallarıyla da yakından ilişki içindedir (Uykur, 2017, s. 3).

Sanat tarihine konu olmuş pek çok eserde görüldüğü gibi sikkeler de ait oldukları dönemin sosyal, siyasal, ekonomik ve dini konuların aydınlatılması açısından önemli belgelerdir. Günümüze dek Artuklu dönemini ele alan kaynakların başında Behzad Butak, XI. XII. XIII. Yüzyllarda Resimli Türk Paraları (Butak, 1947), İbrahim ve Cevriye Artuk'un İstanbul Arkeoloji Müzeleri Teşhirdeki İslami Sikkeler Kataloğu (Artuk ve Artuk, 1970), William F.Spengler ve Wayne G. Sayles tarafından yayınlanan Turkoman Figural Bronze Coins and Their Iconography (SpenglerSayles, 1992) adlı eser, İbrahim Artuk- Cevriye Artuk, Artukoğulları Sikkeleri (Artuk ve Artuk, 1993) ile Ramazan Uykur'un Madenden Yansiyan Tarih (Uykur, 2017), Artuklu Sikkeleriyle ilgili araştırmacılar için önemli kaynaktırlar. Bunların yanı sıra, Ahmet Çaycı tarafından kaleme alınan Selçuklu ve Artuklu Sikkelerinde Zodiak Tasvirleri ile Artuklu Sikkelerinde Hükümdar Tasvirleri adlı çalışmalar, döneme ait sikke araştırılmaları bakımından önemlidir.

Sikke esasında sadece terminolojik olarak madeni para ve üzerindeki motif ve figürlerden oluşan süslemelerden ibaret değildir. Sikkelerden her biri, ulusların tarihi belgeleridir. İçinde çıtığı ulusun sosyal, siyasi, ekonomik, tarihi, dini alanlarını tasvir eden gizemli eserlerdir. Dolayısıyla sikkeler günümüzde karanlıkta kalan çok sayıda soruya yanıt bulmada önemli bir kaynaktır. Yukarıda da ifade edildiği üzere Sanat Tarihi, Arkeoloji, Mitoloji ve Tarih gibi bilim dalları bakımından, bu sahalarda araştırma yapan bilim insanlarına önemli derecede bilgiler kazandırmaya çalışmaktadır. Bu itibarla Şanlıurfa Müzesi'nde bulunan Artuklu dönemine tarihlenen bir grup sikke bu çalışmada ele alınarak, incelenip tanıtılmaya çalışılacaktır. Müzede yer alan Artuklu dönemine ait sikkelerin form, malzeme, teknik ve süsleme programları dikkate alınarak, 12 tanesi incelemeye alınmıştır. Ardından bu eserler sınıfsal ve ikonografik olarak ele alınarak değerlendirilmiş ve kayıt altına alınmışlardır.

\section{Yöntem}

Çalışmaya dâhil edilen bu sikkelerin seçilmesinde öncelik bu alanda yapılan araştırmaları daha da zenginleştirmektir. Sikkeler ile ilgili yapılan bilimsel araştırmaların azlığı bu konuya olan yönelimi doğurmuştur. Müzeden gerekli izinler alındıktan sonra muhafaza altına alınan Artuklu dönemine ait tüm sikkeler çalışma programına dâhil edildi. Bunlar arasında yazı ve süsleme kompozisyonları dikkate alınarak birbirinden farklı oldukları tespit edilen 12 adet sikke değerlendirilmeye alındı. Sikkelerin ölçüleri alınarak fotoğrafları çekildikten sonra çizimleri yapıldı. Ardından sikkenin yapımında kullanılan malzemeyle beraber üzerlerine yazılan yazı ve süsleme unsurlarının çözümlenmesi yapıldı. Eserlere ait sanat özellikleri gün 1şığına çıkarıldıktan sonra Anadolu'nun farklı bölgelerinde üretilen ve farklı müzelerde yer alan benzer sikkelerle karşılaştırmalara gidildi. Değerlendirme süresi tamamlanan sikkelerle ilgili bir sonuca varılarak, sikkelerin Türk ve İslam dünyasındaki yeri tespit edilmeye çalışıldı. 


\section{Bulgular}

\section{Örnek 1:}

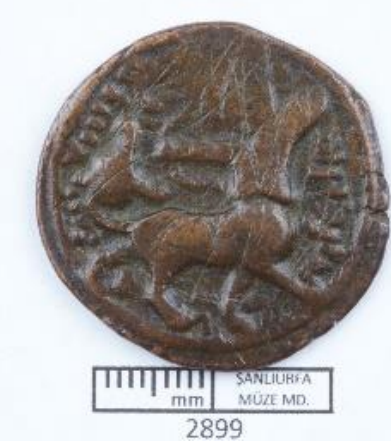

Ön Yüz

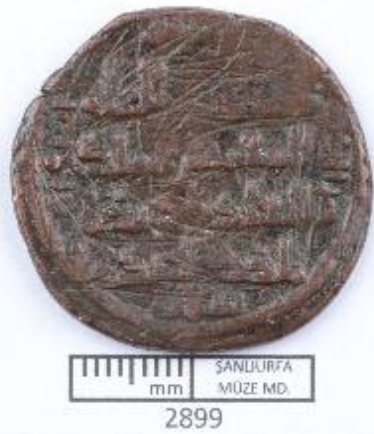

Arka Yüz

Fotoğraf 1a-b, Bakır Sikke, A ̆̆ırlık: 15,3 gr, Çapı: 2,9 cm, Kalınlık: 3 mm.

Dönem: Mardin Artukluları 502-811 (1108-1408)

Hükümdar: Nasruddin Artuk Arslan 597-637 (1200-1239)

Mardin Artuklu hükümdarı Nasruddin Artuk Arslan döneminde üretilmiş sikkenin ön yüzünde, dairesel formlu bir alan içinde kentavros figürü tasvir edilmiştir (Foto 1a; Çizim 1). Yıpranmaların gözlemlendiği eserin ön yüzünde yer alan tasvirler çok net değildir. Çözüldügü kadarıyla hareket halinde olan kentavros, canlı hayata gönderme yapmaktadır. Kuyruğunun ağız kısmı genişçe açılarak, saldırmaya hazır ejder başı şeklinde tasvir edilmiştir. Burada kentavros elindeki ok ve yay ile geriye doğru dönüp ejdere ok atar pozisyondadır. Ok ve yayın kullanılması yay burcuna dikkat çekmektedir (Spengler, W. - Sayles, W.G., 1992, s. 124). Öte yandan ok ve yay tasviri astrolojik kuşaktan yay burcunu sembolize ederken, kuyruk ve ejder ikilemesi ise evren ikonografisi ile astral bir anlam kurmaktadır (Akkaya, 2011, s. 532533).

Figürün etrafındaki yazı kuşağında, "bi-Mardin sene tis'â ve tıs'în hamse mie." ifadesi yer almaktadır. Yazının anlamı: "599 senesinde Mardin' de darp edilmiştir".

$$
\text { Etrafında: بماردين سنة تسع و تسعين و خمسماية }
$$

Sikkenin arka yüzünde daire içine sığdırılmış bir yazı kuşağı bulunmaktadır (Foto 1b). Burada “Emirû'l-Mü'minin el-Melikü'l-Adil Ebubekir Melik-i Diyarbakır.” yazısı okunabilmektedir.

$$
\text { لامير المؤمنين الملك العادل ابو بكر ملك ديار بكر:Ortasinda }
$$

Sikkenin arka yüzündeki merkezine işlenmiş yazı kısmının kenarlarında, üste bin Eyüp, alta Arsalan, sağda en-Nâsır Lidînillâh ve solda da Artuk yazısı bulunmaktadır. Yazı “ Allah'ın dinini yücelten, Müminlerin emiri, adaletli melik Eyüp oğlu Nasıreddin Ebubekir, Diyarbakır Meliki Artuk Arslan" anlamina gelmektedir.

$$
\begin{gathered}
\text { Üst: } \\
\text { بن ايوب } \\
\text { Bin Eyüp }
\end{gathered}
$$




\author{
Alt: \\ ارسلان \\ Arsalan \\ Sağda: الناصر لدين الله \\ En-Nâsır Lidînillâh \\ Solda: ارتق \\ Artuk.
}

\title{
Örnek 2:
}
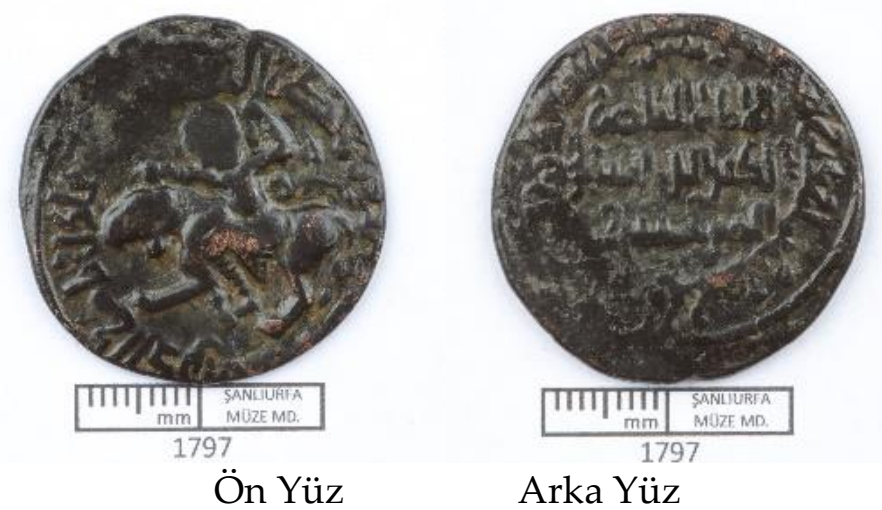

Arka Yüz

Fotoğraf 2a-b, Bakır Sikke, Ağırlık: 7,16 gr, Çapı: 2,9 cm, Kalınlık: 2 mm.

Dönem: Mardin Artukluları 502-811 (1108-1408)

Hükümdar: Nasruddin Artuk Arslan 597-637 (1200-1239)

Mardin Artuklu hükümdarı Artuk Arslan dönemine tarihlenen eserin ön yüzünde, daire formlu bir alan içinde sola doğru hareket halinde tasvir edilmiş binicisiyle birlikte aslan figürü tasviri yer almaktadır (Foto 2a; Çizim 2a). Figürün etrafında "el-Melikü'l-'âlem el-'âdil Nasruddin Artuk Arslan Melik-i Diyarbakır" metninden oluşan bir yazı kuşağı yer almaktadır. Yazının tercümesi şöyledir: “Dini yücelten, âlim, adaletli Diyarbakır Meliki Artuk Arslan".

\section{Etrafinda: الملك العالم العادل الناصر الدين ارتق ارسلان ملك ديار بكر}

Sikkenin arka yüzünde yatay gelişen bir kompozisyonda yer alan 3 satırlık yazı, bir daire içinde gösterilmiştir (Foto 2b; Çizim 2b). Bu bölümde dönemin Abbasi Halifesinin adı ve unvanına yer verilmiştir. Daire içinde "el-İmam en-Nâsır Lidînillâh Emirû'l-Mü'minin" olarak yazı işlenmiştir. Bu yazı kompozisyonunun etrafında ayrı bir yazı kuşağı daha bulunmaktadır. Burada da Eyyubi hükümdarını tanımlayan "el-Melikü'l-Âdil Seyfe'd-din Ebu Bekir bin Eyyûb" yazısı yer almaktadır. Yazının anlamı şu şekildedir: "Allah'ın dinini yücelten, Müminlerin emiri, adaletli Eyüp oğlu Seyfeddin Ebu Bekir".

$$
\begin{aligned}
& \text { Ortasinda: } \\
& \text { الامام الناصر لدين الله امير المؤمنين } \\
& \text { Etrafinda: } \\
& \text { الملك العادل سيف الدين ابو بكر بن ايوب }
\end{aligned}
$$




\section{Örnek 3:}

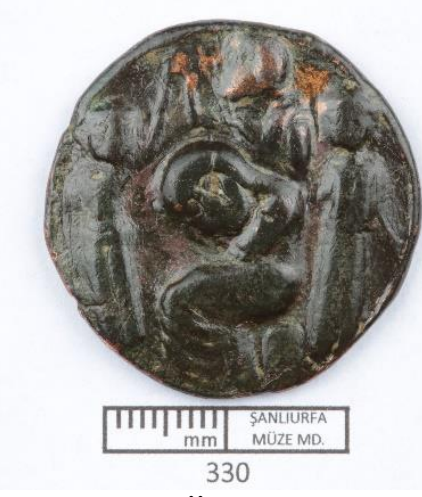

Ön Yüz

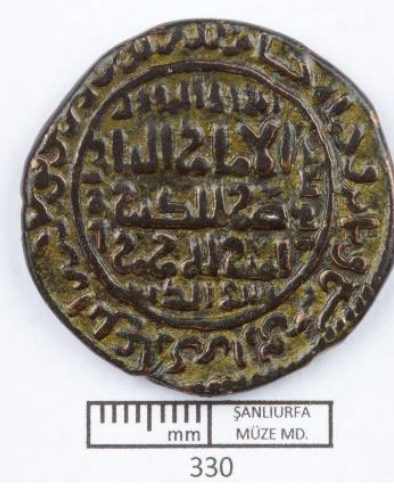

Arka Yüz

Fotoğraf 3a-b, Bronz Sikke, Ağırlık: 14,2 gr, Çapı: 30 mm, Kalınlık: 3 mm.

Dönem: Mardin Artukluları 502-811 (1108-1408)

Hükümdar: Hüsam el-Din Yuluk Arslan 580-597 (1184-1200)

Sikkenin ön yüzünde sikkenin merkezine oturtulmuş başı öne doğru uzanan profilden verilmiş bir kadın figür yer almaktadır (Foto. 3a; Çizim 3a). Merkeze konumlanan ağlayan kadının etrafında ayakta duran 3 kadın figürü daha yer almaktadır. Dairesel formlu bir alan içine sıkıştırılmış figürlerin duruş pozisyonu birbirinden farklılık göstermektedir.

Sikkenin arka yüzünde Halife Nasır ile hükümdar Hüsameddin Yuluk'a ait bilgiler yer almaktadır (Foto 3b; Çizim 3b). Mardin Artuklularına ait sikkenin arka yüzeyi, çember şeklinde iç içe geçmiş iki daireden meydana gelen bir bezemeye sahiptir. Ortadaki dairenin içine el-İmam Nasruddin Emirû'l-Mü'minin yazısı işlenmiştir.

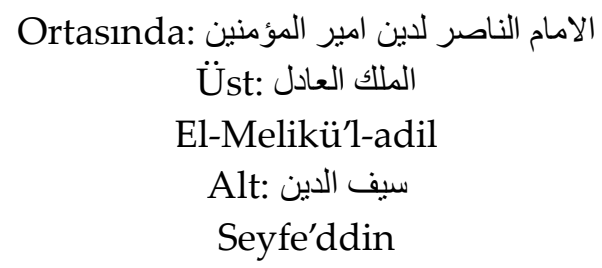

Ortada yer alan yazının etrafını çevreleyen bir yazı kuşağı daha bulunmaktadır. Burada da Ebu Bekir bin Eyüp, Hüsam'ed-din Melik-i Diyarbakır Yuluk Arslan bin İl Gazi bin Artuk sene tis'â ve semânin ve hamse mie. (H.589 / M.1193) yazısı yer almaktadır. Yazı, “Dini yücelten, Müminlerin emiri, adaletli Eyüp oğlu Seyfeddin Ebu Bekir, Diyarbakır meliki Artuk oğlu İ Gazi oğlu Hüsameddin Yuluk Arslan, (H.589 / M.1193)" anlamına gelmektedir.

\section{Etrafinda:}

ابو بكر بن ايوب حسام الدين ملك ديار بكر يولق ارسلان بن ايل غازي بن ارتق سنة تسع و ثمانين وخمس مائة

\section{Örnek 4:}




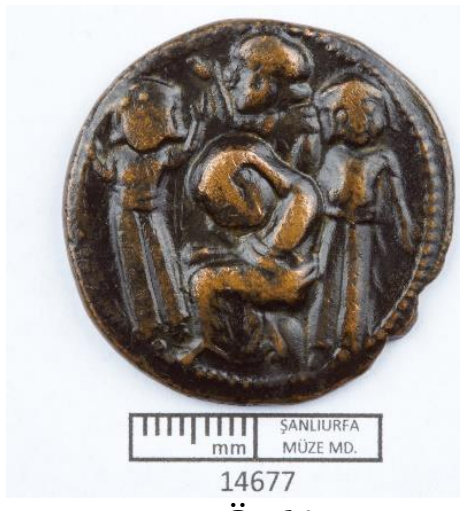

Ön Yüz

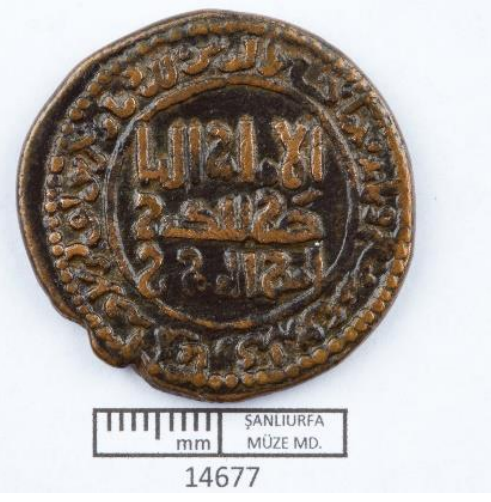

Arka Yüz

Fotoğraf 4a-b, Bronz Sikke, Ağırlık: 15,3 gr, Çapı: 31 mm, Kalınlık: 3 mm.

Dönem: Mardin Artukluları 502-811 (1108-1408)

Hükümdar: Hüsam el-Din Yuluk Arslan 580-597 (1184-1200)

Sikkenin ön yüzü 1 numaralı örnekle ile aynı süsleme kompozisyona sahiptir. Noktasal tekrarlardan oluşan dairesel bir dizilim içine yerleştirilen figürler örnek 3'te tanıtılan sikkeden daha sağlam olarak günümüze ulaşmıştır. 3 numaralı örnekteki sikkede olduğu gibi burada da profilden sola dönük biçimde tasvir edilmiş kadın figürü, başı öne doğru eğik şekilde yas tutmaktadır (Foto. 4a; Çizim 4a). Ağlayan kadın figürünün etrafında da olasılıkla ağıt yakan 3 insan figürü daha resmedilmiştir.

Mardin Artuklularına ait sikkenin arka yüzünde Halife Nasır ile hükümdar Hüsameddin Yuluk'a dair bilgilere yer verilmiştir (Foto. 4 b; Çizim 4 b). Sikkenin arka yüzeyinde yer alan bu bilgiler iç içe geçmiş iki dairesel formlu bölüm içinde yer almaktadır. Ortadaki dairede yer alan kısımda el-İmam Nasruddin Emirû'l-Mü'minin yazısı işlenmiştir.

Ortasinda: الامام الناصر لدين امير المؤمنين

Ortada yer alan yazıyı çevreleyen bir diğer yazı kuşağı noktasal tekrarlardan oluşan bir dizilime sahiptir. Bu kuşağın içinde Hüsam'ed-din Melik-i Diyarbakır Yuluk Arslan bin İl Gazi bin Artuk sene tis'â ve semânin ve hamse mie (H.589 / M.1193). Yazı, "Dini yücelten, Müminlerin imamı ve emiri Diyarbakır meliki Artuk oğlu İl Gazi oğlu Hüsameddin Yuluk Arslan (H.589 / M.1193)" anlaminı vermektedir.

Etrafında: حسام الدين ملك ديار بكر يولق ارسلان بن ايل غازي بن ارتق تسع و ثمانين وخمس مائة

\section{Örnek 5:}




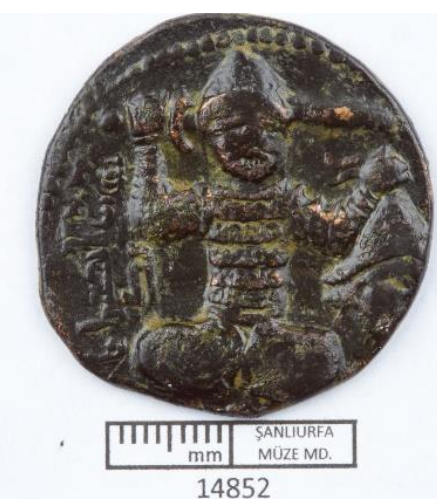

Ön Yüz

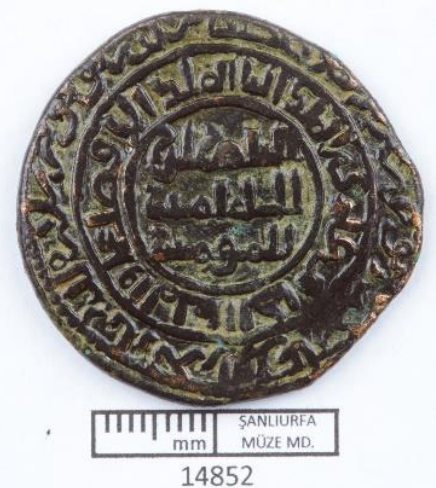

Arka Yüz

Fotoğraf 5a-b, Bronz Sikke, Ağırlık: 9,85 gr, Çapı: 33 mm, Kalınlık: 2,2 mm.

Dönem: Mardin Artukluları 502-811 (1108-1408)

Hükümdar: Hüsam el-Din Yuluk Arslan 580-597 (1184-1200)

Sikkenin ön yüzünde noktasal tekrarlardan oluşan dairesel formlu bir alan içinde, eskiden beri Türk kültüründe yer alan ve Türk oturuşu olarak da bilinen bağdaş kurma pozisyonunda oturan bir figür bulunmaktadır (Foto. 5a; Çizim 5a). Miğfer ve zırhlarını giyinmiş bir savaşçı şeklinde tasvirlenen figürün sağ elinde bir kılıç yukarıya doğru kaldırmış, sol elinde ise bir kelle bulunmaktadır. Figürün sağ tarafında Nure'd-din Atabek yazısı yer almaktadır.

$$
\text { Sağda : نور الدين اتابك }
$$

Mardin Artuklularına ait sikkenin arka yüzünde, halife Nasır ve hükümdar Hüsameddin Yuluk isimleri yer almaktadır (Foto. 5b; Çizim 5b). Sikkenin bu yüzünde çember şeklinde iç içe geçmiş 3 daire bulunmaktadır. Merkezde yer alan daire içinde en-Nâsır Lidînillâh Emirû'lMü'minin yazısı yer almaktadır. Merkezdeki daireyi kuşatan bir diğer daire içinde Eyyubi melikleri el-Melikü'l-Efdal Ali ve el-Melikü'l-Zahir Gazi bin el-Melik yazısı işlenmiştir. En dıştaki dairede ise Hüsam'ed-din Yuluk Arslan bin İl Gazi bin Artuk yazısı bulunmaktadır. Yazı, "Allah'ın dinini yücelten, Müminlerin emiri, faziletli, Artuk oğlu İl Gazi oğlu Hüsameddin Yuluk Arslan oğlu Melik Ali ve Melik Zahir" şeklinde bir anlam vermektedir.

Merkezdeki daire: الناصر لدين الله امير المؤمنين

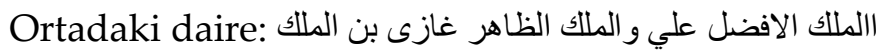

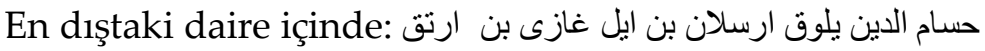

\section{Örnek 6:}
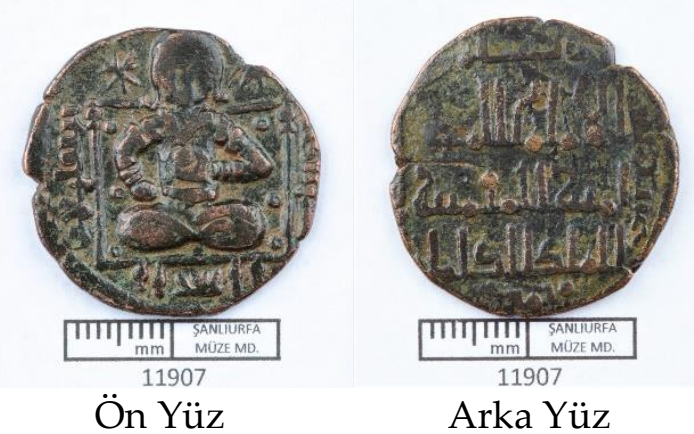
Fotoğraf 6a-b, Bakır Sikke, Ağırlık: 7,20 gr, Çapı: 2,7 cm, Kalınlık: 2 mm.

Dönem: Mardin Artukluları 502-811 (1108-1408)

Hükümdar: Nasır el-Dîn Artuk Arslan 597-637 (1200-1239)

Mardin Artuklu hükümdarı Nasır el-Din Artuk Arslan dönemine tarihlenen bu örnekteki figürün bir tahtta gösteriliyor olmasından dolayı diğerlerinden ayrılmaktadır. Türk kültüründe çok eskilere dayanan bağdaş kurma pozisyonu şeklinde gösterilen figür, sikkenin merkezine yerleştirilmiştir (Foto 6a; Çizim 6a). Bir siluet şeklinde tasvir edilmiş figürün sağ eli dizinin üzerindeyken sol eli ise göğsünün üzerinde bir küre tutarak resmedilmiştir. Figürün sağ tarafında Artuk Aslan, sol tarafında ise Nasruddin yazısı yer almaktadır.

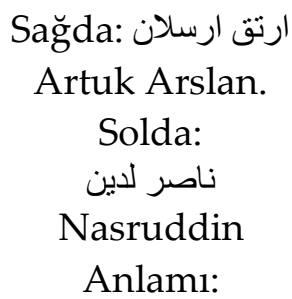

Dinin yardımcısı Artuk Arslan

Sikkenin arka yüzünde dairesel formlu alan içinde istiflenmiş yazılar mevcuttur (Foto. 6b; Çizim 6b). Burada Halife el-Müstansır ile Eyyubi melikine ait isimler zikredilmiştir. Yazıda “el-İmam'ül-Müstansır Emirû'l-Mü'minin el-Melikü'l-Kamil” yazısı görülmektedir. Yazı,

“Müminlerin emiri, imamı Müstansır Billâh, kusursuz melik Muhammed" demektedir.

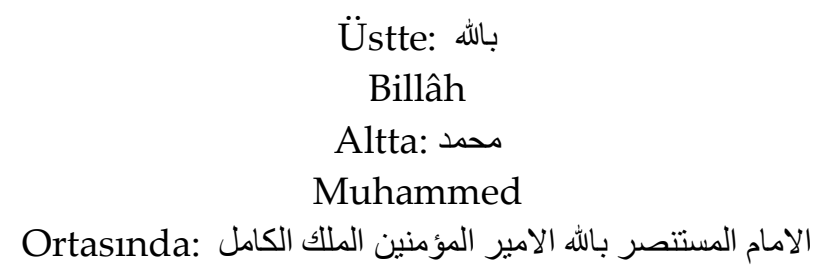

\section{Örnek 7:}
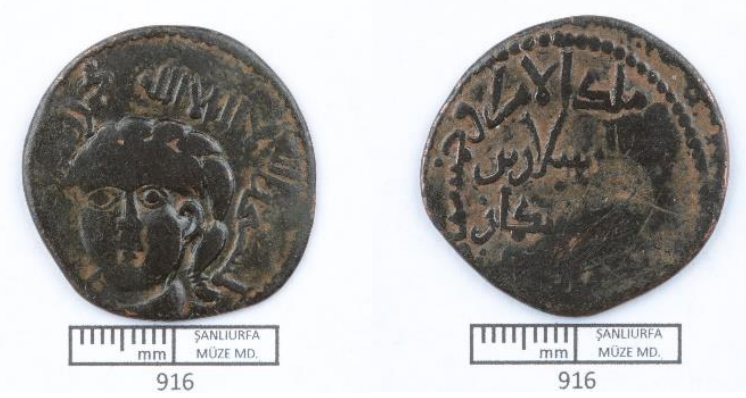

Fotoğraf 7a-b, Bakır Sikke, Ağırlık: 12,85 gr, Çapı: 30 mm, Kalınlık: 3mm.

Dönem: Hisn-1 Keyfa-Âmid Artukluları 495-811 (1101-1408)

Hükümdar: Fahreddin Kara Arslan 543-570 (1148-1174)

İnci tanelerinden oluşan daire kesitli bir dizilim içinde 3/4 kalıbı kullanılarak resmedilmiş bir portre, sikkenin ön yüzüne yerleştirilmiştir (Foto. 7a; Çizim 7a). Porte diğer örneklerden farklı olarak sikkenin tam merkezinde değil aşağıya doğru kaydırılmış bir konumdadır. Bundan 
dolayı yazı da sikkede diğer boş kalan yerlere yerleştirilmiştir. Büyük gözlü, dolgun ve yuvarlak yüzlü olarak resmedilmiş figürün etrafında, El-Müstencid Billâh Lâ ilâhe illallâh Muhammedün Resûlullâh yazısı mevcuttur. Yazının anlamı şöyledir: "Müstencid Billâh, Allah'tan başka ilah yoktur. Muhammed Aleyhissalatü vesselam da Onun Resulüdür".

$$
\text { Etrafında: المستتجد بالله لااله الا الله محمد رسول الله }
$$

Hısn-1 Keyfa-Amid Artuklu hükümdarı Fahreddin Kara Arslan dönemine ait sikkenin arka yüzünde oksidasyona bağlı olarak karartılar mevcuttur (Foto 7b; Çizim 7b). Oluşan bu karartılardan dolayı yazının bir kısmı tam olarak okunamamaktadır. Sikkenin orta kısmında “Melikü'l-Umera Arslan bin Sökmen” yazısı yer almaktadır. Yazı “Emirlerin Meliki Sökmen oğlu Arslan" anlamına gelmektedir.

Ortasinda: ملك الامر اء ارسلان بن سكمان

Figürün etrafında da karartılardan dolayı tam olarak okunmayan “.............hamse 'mie, (H.5..... / M.11.....-11......M).

Etrafinda: تمسئة

\section{Örnek 8:}

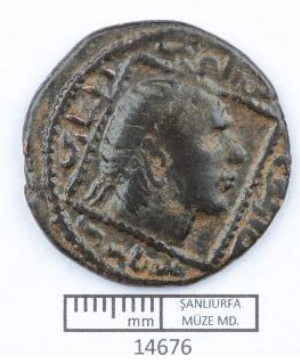

Ön Yüz

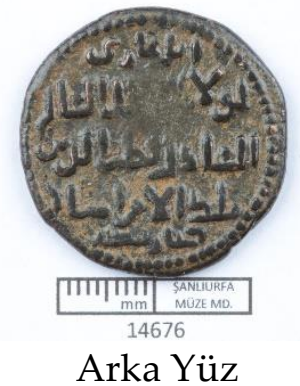

Arka Yüz

Fotoğraf 8a-b, Bronz Sikke, A ğırlık: 10 gr, Çapı: 2,9 cm, Kalınlık: 3mm.

Dönem: Mardin Artukluları 502-811 (1108-1408)

Hükümdar: II. Kutb el-Din İl-Gazi 572-580 (1176-1184)

Mardin Artuklu hükümdarı II. Kutb el-Din il-Gazi döneminde üretilmiş eserin ön yüzünde noktasal tekrarlardan oluşan dairesel kesitli bir dizilim içinde, aynı formatta oluşturulmuş kare formlu bir dizilim, sikkenin merkezine 4 kollu yıldız şeklinde oturtulmuştur (Foto. 8a). Eserdeki büst sağ taraftan profilden tasvir edilerek, karşı tarafa düz bir şekilde bakmaktadır. Yıldız şeklindeki formun boş kalan köşelerinde, Timurtaş il-Gâzi bin Albi (Alpi) bin Artuk yazısı işlenmiştir. Yazı, "Artuk oğlu Albi (Alpi) oğlu Timurtaş İl gazi” anlamındadır.

Etrafında: تمرتاش ايل غازي بن البى بن ارتق

Sikkenin arka yüzünde diğer eserlerin çoğunda olduğu gibi noktasal tekrarlardan oluşan daire kesitli bir dizilim içinde bir yazı istif edilmiştir (Foto. 8b). Burada "li-Mevlâ el-Melikü'l-âlem el-Âdil Kutbed-din Melikü'l-Umera Şâh" yazı yer almaktadır. Yazı tam olarak okunduğunda, 
“Diyarbakır Şahı, âlim, adaletli, Emirlerin Meliki, İl Gazi Mevla İl Kutbettin” anlamına gelmektedir.

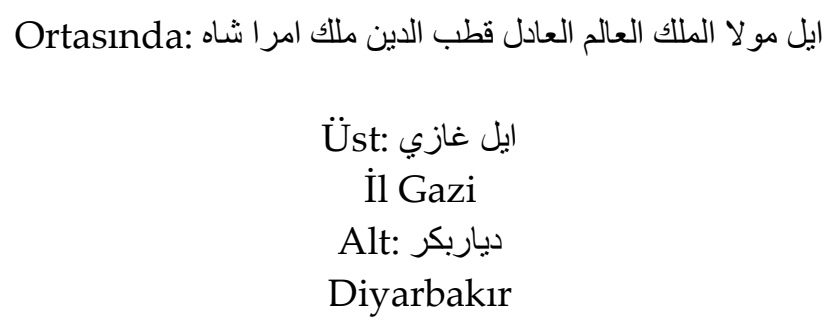

\section{Örnek 9:}

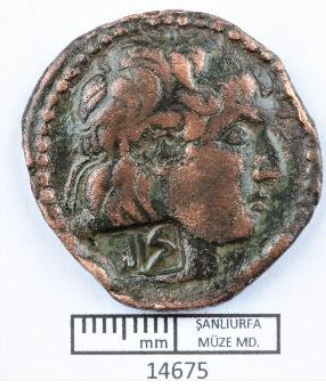

Ön Yüz

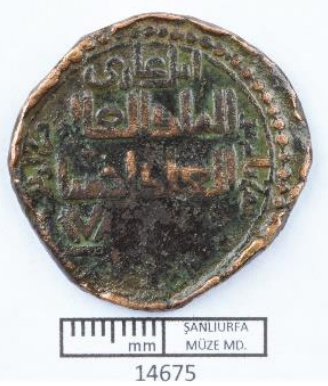

Arka Yüz

Fotoğraf 9a-b, Bronz Sikke, Ağırlık: 13,3 gr, Çapı: 29 mm, Kalınlık: 2 mm.

Dönem: Mardin Artukluları 502-811 (1108-1408)

Hükümdar: Hüsam el-Din Timurtaş 516-547 (1122-1152)

Mardin Artuklu hükümdarı Hüsam el-Din Timurtaş zamanında darp edilmiş bir sikkedir. İnci diziliminden meydana gelmiş dairesel formlu bir alan içinde başı diademli, iri gözlü, dolgun yüzlü sağa doğru profilden verilmiş bir figür yer almaktadır (Foto. 9a). Figürün boynu üzerinde Necmeddin yazısı işlenmiştir.

Boynunda: نجم الدين

Necmed-din.

Sikkenin arka yüzeyinde diğer eserlerde olduğu gibi noktasal tekrarlardan oluşan bir daire içinde el-Melikü'l-'âlem el-'âdil Hüsam'ed-din yazısı yer almaktadır (Foto. 9b). Yazı tam olarak okunduğunda, “Artuk oğlu Hüsameddin Timurtaş, âlim ve adaletli melik Necmeddin İl gazi" şeklindedir.

Ortasında: الملك العالم العادل حسام الدين

Ortada yer alan yazının çevresinde de;

Üst: ايل غازي

İl Gazi

Sağda:

تمرتاش بن

Timurtaş bin

Sol: بن ارنق 


\section{Bin Artuk}

\section{Örnek 10:}

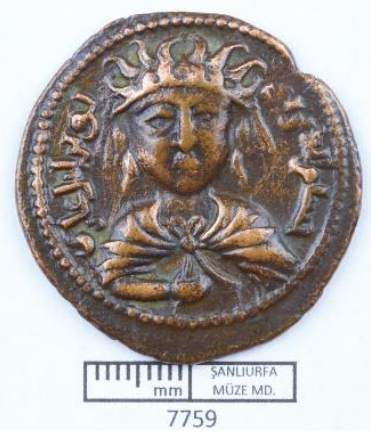

Ön Yüz

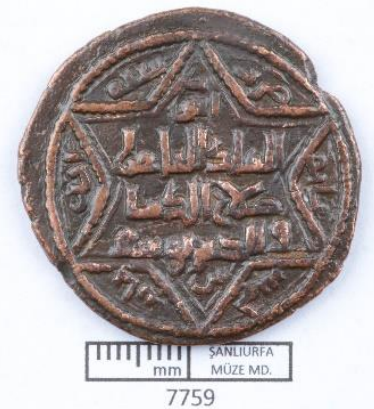

Arka Yüz

Fotoğraf 10a-b, Bakır Sikke, Ağırlık: 14,26 gr, Çapı: 30 mm, Kalınlık: 3,2 mm.

Dönem: Mardin Artukluları 502-811 (1108-1408)

Hükümdar: Hüsam el-Din Yuluk Arslan 580-597 (1184-1200)

Sikkenin ön yüzünde noktasal tekrarlarla sınırları belirlenmiş dairesel bir form içinde cepheden tasvir edilmiş bir portre yer almaktadır (Foto. 10a; Çizim 8a). Ateş alevini andıran erkek figürün saçları dalgalı ve geriye doğru uzanmaktadır. Çengelli bir iğneyle tutturulmuş drapeli elbisesi mevcuttur. Figürün etrafını çevreleyen bir kuşakta Hüsam'ed-din Yuluk Arslan şeklinde bir yazı vardır.

\section{Etrafında: حسام الدين يولق ارسلان}

Mardin Artuklu hükümdarı Hüsameddin Yuluk dönemine tarihlenen Sikkenin arka yüzünde, inci taneli bir dizilimden oluşan daire içinde 6 kollu bir yıldız bulunmaktadır (Foto. 10b; Çizim $8 b)$. Burada 5 satır yazıyla Eyyubi meliki el-Melikü'l-nasır Salaha'd-dinya ve'd-din Yusuf yazısı bulunmaktadır.

$$
\begin{aligned}
& \text { Ortasinda: } \\
& \text { الملك الناصر } \\
& \text { صلاح الدنيا } \\
& \text { و الدين يوسف الانف } \\
& \text { Üstte: ايوب } \\
& \text { Eyüp } \\
& \text { Altta: بن } \\
& \text { Bin } \\
& \text { Etrafında: } \\
& \text { ضرب سنة احد وثمانين و خمس مائة }
\end{aligned}
$$

Yıldızın dıştan köşelerinde ise sikkenin üretim tarihi ile ilgili bilgiler içermektedir. Bu kısımda Duribe sene îhde ve semânin ve hamse mie (581.H-1185-1186.M) yazısı yer almaktadır. Yazının tercümesi " Dünyanın ve dinin yardımcısı, Eyüp oğlu Melik En-Nasır Yusuf, 581 senesinde darp edilmiştir" şeklindedir. 


\section{Örnek 11:}

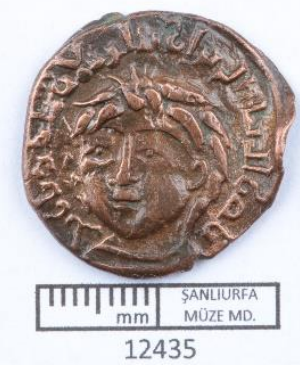

Ön Yüz

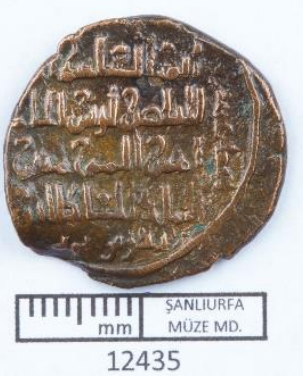

Arka Yüz

Fotoğraf 11a-b, Bakır Sikke, Ağırlık: 6,61 gr, Çapı: 22 mm, Kalınlık: 2 mm.

Dönem: Mardin Artuklularr 502-811 (1108-1408)

Hükümdar: Nasruddin Artuk Arslan 597-637 (1200-1239)

Mardin Artuklu hükümdarı Nasruddin Artuk Arslan dönemine tarihlenen sikkenin ön yüzünde daire içinde, 3/4 cepheden verilmiş bir büst yer almaktadır (Foto. 11a; Çizim 9a). Yuvarlak dolgun yüzlü figürün saçı dağınık olarak tasvir edilmiştir. Figürün etrafındaki yazı kuşağında, Mardin Artukluları zamanında hükümdar en-Nasre'd-dünya ve'd-din Artuk Arslan, Melik-i Diyarbakır yazısı yer almaktadır. Yazının anlamı: "Dünyanın ve dinin yardımcısı, Diyarbakır meliki Artuk Arslan” şeklindedir. .

$$
\text { Etrafında: الناصر الدنياو الدين ارتق ارسلان ملك ديار بكر }
$$

Eserin arka tarafı da tamamen yazı ile doldurulmuştur. Eserin merkezinde Ahmed en-Nâsır Lidînillâh Emirû'l-Mü'minin el-Melikü'l-Adil"' yazısı yer almaktadır (Foto. 11b; Çizim 9b).

Eserin arka yüzünde ayrıca sağ ve sol taraflarda dikey olarak yazılmış yazılar da yer almaktadır. Üste- Ebu'l-Abbâs alta- Ebu Bekir bin Eyyûb Sağda- ihde aşer; Solda- ve sitte 'mie. (H. 611-M. 1214/1215), tarihi yer almaktadır. Yazının anlamı, "Allah'ın dinini yücelten, Müminlerin emiri, adaletli Eyüp oğlu Ebu Bekir, Ebu Abbas”" şeklindedir.

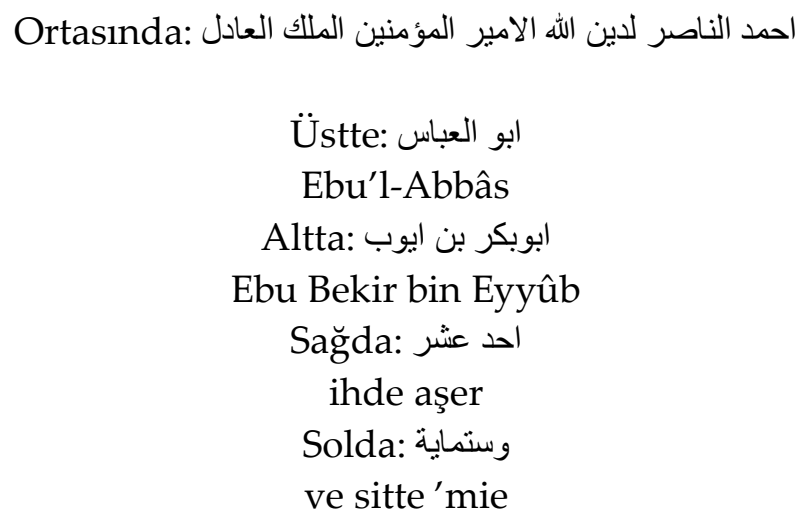

\section{Örnek 12:}




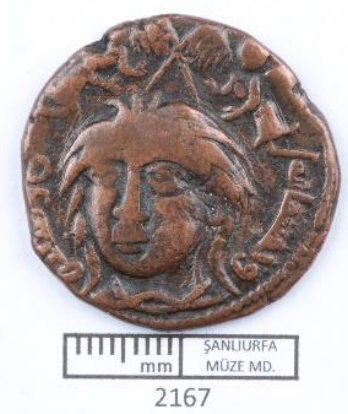

Ön Yüz

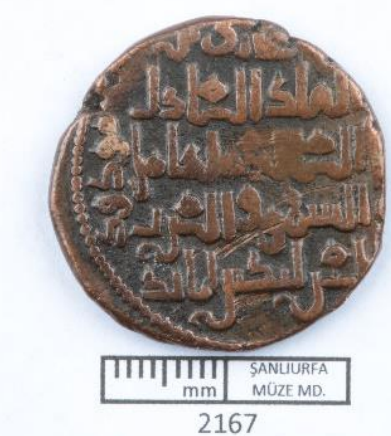

Arka Yüz

Fotoğraf 12a-b, Bakır Sikke, Ağırlık: 15,3 gr, Çapı: 31 mm, Kalınlık: 2,7 cm.

Dönem: Zengî - Musul Atabeyleri H. 521-631 (M. 1127-1233)

Hükümdar: II. Seyfeddin Gazi bin Mevdud H. 565-576 (M. 1169-1180)

İncelenen bu örnek müzedeki envanter kayıtlarına göre Artuklu dönemi olarak kayıt altına alınmış. Ancak sikke üzerinde yapılan analizler sonucunda sikkenin Artuklular dönemine ait olmayıp Zengi dönemine ait bir sikke olduğu anlaşılmıştır. Zengi dönemi figürlü bakır sikkeleri ile Artuklu dönemi figürlü sikkelerinde betimlemeler birbirinin tekrarı gibidir.

Ön yüzde dairesel formlu bir alan içinde $3 / 4$ profilden verilmiş portredeki figürün yüzü hafifçe sağa dönük olarak tasvir edilmiştir (Foto. 12a; Çizim 10a). İri olarak resmedilmiş badem gözleri ile elmacık kemiklere sahip hükümdar portresidir. Yuvarlak dolgun yüzlü figürün saçları dağınık olarak tasvir edilmiştir. Figürün baş hizasında sağ ve sol tarafta elinde kase tutacak şekilde tasvir edilmiş küçük melek figürü işlenmiştir. Yoğun oksidasyona uğrayan eserdeki figürün etrafını çevreleyen yazı kuşağı tam olarak okunamamıştır. Okunabildiği kısım aşağıya çıkarılmıştır.

\section{Etrafında: ت} ve seb'in ve hamse mie.

(H.57... / M.117...-117....M)

Sikkenin arka yüzünde boşluk bırakılmayacak şekilde yazı ile doldurulmuştur (Foto. 12b; Çizim 10b). Merkezde “el-Melikü'l-'âdil / el-'âlem Melikü’l-Umera / eş-Şark ve'l-Garb / Tugrul tekin Atabek" yazısı işlenmiştir. Bunun yanı sıra, merkezdeki yazıyı çevreleyen kısımlarda, solda Mevdud, üstte Gazi bin, sağda Seyfe'ddin yazısı işlenmiştir. Yazının anlamı: "Emirlerin meliki, doğu ve batının hâkimi Tuğrul Tekin Atabek ve adil ve âlim Mevdud oğlu Seyfeddin Gazi".

$$
\begin{aligned}
& \text { Ortasinda: الملك العادل العالم ملك امر ا الثرق و الغرب طغرل تكين اتابك } \\
& \text { Merkezdeki yazıyı çevreleyen yazılar } \\
& \text { Solda: مودود } \\
& \text { Mevdud } \\
& \text { ن̈stte : غازي بن } \\
& \text { Gazi bin } \\
& \text { Sağda: سيف الدين } \\
& \text { Seyfe'ddin. }
\end{aligned}
$$




\section{Değerlendirme ve Sonuç}

\section{$>\quad$ Dönem Bilgisi}

Değerlendirilmeye alınan sikkeler üzerinde yapılan analizler sonucunda, sikkelerin birden fazla değerlerinin olduğu tespit edilmiştir. Özellikle de sanat tarihi ve tarih açısından ne denli önemli oldukları, sikkeler üzerine işlenen bezeme ve tarihi bilgilerden anlaşılmıştır. Müzenin ilgili bölümünde muhafaza edilen 450 sikkeden toplam 12 tanesi incelemeye alınmıştır. Analizler sonucunda değerlendirilmeye alınan 12 sikkeden 1 tanesinin Zengi dönemine ait olduğu tespit edilmiştir. Örneklerin seçiminde, sikkeler üzerine işlenen figürler belirleyici olmuştur. Çalışmada tekrardan kaçma adına, tıpkıbasım olanlar ile birbirine çok benzeyen figürlü sikkelerden birer örnek değerlendirilmeye alınmıştır. Seçilen Artuklu örneklerinden 10 adedi Mardin Artuklularına aitken 1 adedi Hısn-1 Keyfa-Amid Artuklularına aittir. Örneklerden 1,2,5,6 ve 11'dekiler Mardin Artukluları dönemi hükümdar Nasruddin Artuk Arslan; 3, 4, 10' dakiler hükümdar Hüsameddin Yuluk; örnek 9' daki hükümdar Hüsam el-Din Timurtaş ile örnek 8'deki sikke hükümdar II. Kutb el-Din il-Gazi dönemine tarihlenirken, geriye kalan örnek 7'deki sikke ise Hısn-1 Keyfa-Amid Artukluları zamanında hükümdar Fahreddin Kara Arslan dönemine aittir.

\section{$>$ Darp Bilgisi}

Değerlendirilmeye alınan sikkelerden bazı örnekler üzerinde darp yeri ve tarihine ilişkin bilgiler mevcutken, örnek no 2, 5, 6, 8 ve 9'daki sikkeler üzerinde ise darp bilgisine rastlanamadı. Geriye kalan örnek 9'daki eser ise yıpranmadan dolayı tam okunamadı. Aşağıda resmi gösterilen ve farklı müzelerde bulunan Artuklu dönemine ait sikkelerle yapılan karşılaştırmalardan, çalışmaya dahil edilen sikkelerden örnek 2'nin Mardin'de 606 (1209-10) tarihinde darp edildiği (Foto. 13-14); örnek 5'in Diyarbakır'da 596/597 (1199-1200) tarihinde darp edildiği (Foto. 15-16); örnek 6'nın 628 (1230-1231) tarihinde darp edildiği (Foto. 17) ve örnek 8'in Diyarbakır'da 572-582 (1184-1185) tarihinde darp edildiği (Foto. 18) sonucuna varılmıştır. Geriye kalan örnek 7 ve 9 ile ilgili benzer örneklerinde bazılarında darp tarihi okunamadı, bazılarında da darp bilgisi bulunamadı. Yapılan analizlerde örnek 7' deki sikkenin darp bilgisinin kısmen okunabildiğinden yola çıarak 500 (M. 11..)'lü yıllarda darp edildiği ve örnek 9'da sikkenin üzerindeki hükümdar isminden 516-547 (1122-1152) tarihleri arasında darp edildiği düşünülmektedir.

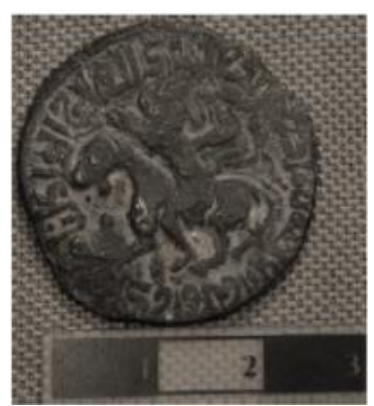

Fotoğraf 13

Kahraman Maraş Müzesi (G. Aydoğdu'dan)

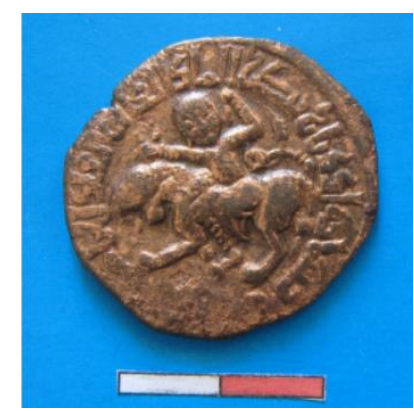

Fotoğraf 14

Mardin Müzesi (R. Uykur'dan) 


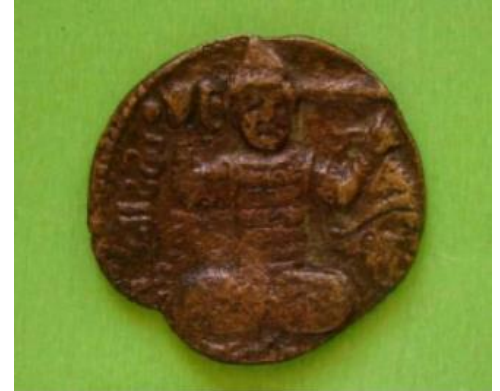

Fotoğraf 15

Mardin Müzesi (N. Akkaya'dan)

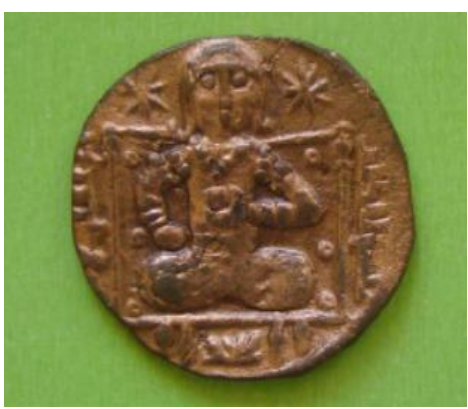

Fotoğraf 17

Mardin Müzesi (N. Akkaya'dan)

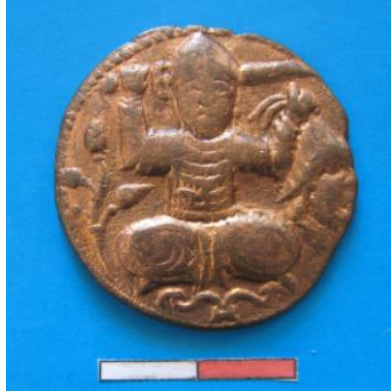

Fotoğraf 16

Mardin Müzesi (R. Uykur'dan)

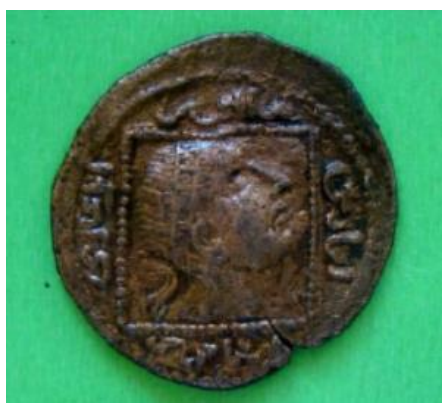

Fotoğraf 18

Mardin Müzesi (N. Akkaya'dan)

\section{$>$ Malzeme Bilgisi}

Ortaçağ Anadolu'sunda İslami dönem sikkeleri temelde altın, gümüş, bakır ve bronzdan imal edilmiştir. Bu dönemde Müslüman devletlerarasında en çok sikke basan Artuklular, yoğun olarak bakırdan ürettikleri sikkelerin yanı sıra, kısmen de olsa gümüş sikke darp ettikleri görülmektedir (Artuk ve Artuk 1993, s. 9). Çalışmaya dahil edilen 11 tane Artuklu sikkesinden 6 adeti (Örnek no: 1,2,6,7,10,11) bakır malzemeden yapılmışken, geriye kalan 5 adeti bakırın önemli bir alaşımı olan bronzdan yapılmıştır (Örnek no:3,4,5,8,9). Müzede Artuklu sikkesi olarak kayıt altına alınan Zengi dönemine ait sikke ise bakır madeninden üretilmiştir (Örnek no 12).

\section{$>$ Süsleme Bilgisi}

İncelenen eserlerin üretiminde bakır ve bronzun kullanıldığ figür çeşitliliği ile dikkat çekmektedir. Figürlerin kol ve bacaklarının bükülüşü, hareket halinde oluşları ile düz bir fon üzerinde gösterildiği izlenimi tasvirler, kompozisyonlarda bir silüet üslubuna yol açsa da inci dizilerinden oluşan çerçevelerin bulunması sikkelere renklilik katmıştır.

\section{$\checkmark \quad$ Figürlü Süsleme}

İnsan figürlerinin yanında hayvan figürleri ile mitolojik bir yaratık olan kentavros figürü de bulunmaktadır (Foto. 1a-b). Kentavroslar eski çağlardan beri sanatçılara konu olmuştur. At ile insan karışımı olan kentavroslar, ön cepheden bakıldığında baş, göğüs ve kolları insan, geride kalan diğer bölümleri de at şeklindedir. Çalışmaya konu olan sikkelerden birinin üzerinde aslan figürü tasviri bulunmaktadır (Foto. 2a). Bu örnekteki kompozisyon aslana binmiş hükümdar tasvirini konu almıştır. Analiz edilen örnekler arasında en ilginç kompozisyona sahip olanlar ise kalabalık olarak tasvirlenen insan figürlerinin yer aldığ1 sikkelerdir (Foto 3a; 4a). Kalabalık sahnelerin işlendiği bu sikkeler diğer sikkelere oranla canlı hayata adeta 
gönderme yapmaktadırlar. Kalabalık olarak işlenen bu sikkelerdeki kompozisyonlarda yer alan figürlerin kederli duruşları ile sikke üzerinde yer alan yazılar arasında bir ilişki kurulamamıştır. Sahnenin Türk geleneklerine uygun olarak kına gecesinde ağlayan gelin betimlemesi olarak yorumlanabileceği gibi, ölüm üzerine matem kompozisyonunun tasvir edildiği de söylenebilir. Devlet tarafından sikkelerin basıldığı göz önüne alındığında, yukarıda anlatılan iki durumda da tasvir edilen kompozisyondaki sahne önemli bir olayla ilgili olduğu düşünülmektedir. Bu çalışmada ele alınan sikkeler arasında bir de hükümdar ve diğer insan figürleri tasvirlerinin işlendiği örnekler mevcuttur (Foto. 5a-11a). Malazgirt zaferinden sonra Anadolu'ya akınlar düzenleyip fethettikleri topraklara yerleşen Türk hükümdarlarının, hükümdar tasvirlerini kendi sikkelerinde kullandıkları bilinmektedir. Bu dönemde görülen bu yaklaşım Bizans sikkelerinde görülen $\mathrm{Hz}$. İsa ve hükümdar tasvirleri kompozisyon geleneğinden etkilenmiş olabileceği düşünülmektedir. Zira bu dönemde Bizanslılarla ticaret gibi bazı konularda karşılıklı bir etkileşim içinde oldukları bilinmektedir. Ele alınan sikkelerde görülen hükümdar ve diğer insan tasvirleri büst şeklindedir. Bunun yanı sıra, Türk hükümdarları sikkelerde Orta Asya Türk tipi ve geleneklerinin de yar aldığı tasvirlere özen göstermiştir. Figürlerin yüz şekline yansıyan dolgun yanaklı, badem gözlü, ay yüzlü gibi öne çıan detaylar ile Türk oturuşu olarak bilinen bağdaş kurarak oturma biçimi ele alınan Artuklu sikkelerin bazı örneklerinde görülmektedir (Foto. 5a; 6a).

\section{$\checkmark$ Geometrik Süsleme}

Değerlendirmeye alınan sikkeler üzerinde süsleme düzeni açısından bakıldığında, figürsel süsleme dişında geometrik süslemelerin de kendine yer bulduğu görülür. Geometrik süslemeler Türk sanatının her alanında kendine yer bulmuştur. İncelenen örneklerde daire, kare ve yıldız motifleri şeklinde sikkeler üzerinde işlenmiştir. Sikkelerin ön yüzünde dairesel noktalardan oluşan tekrarla meydana gelen dairesel şekiller kullanılmışken bir örnekte kare formlu bir dizilim, sikkenin yüzeyine 4 kollu yıldız biçiminde oturtulmuştur (Foto. 8a). Geometrik şekiller sikkenin arka yüzünde de görülmektedir. Yazıların istif edildiği daire ve inci dizisinden daire formlu şekiller dişında, iç içe geçmiş daireler ile 6 kollu yıldız motifler, sikkenin arka yüzünü süslemektedir. Bu geometrik şekiller bütünsel kompozisyonda merkezdeki yatay yazıları içerisine alarak, yazıların ön plana çıkmasını sağlamıştır.

\section{$\checkmark$ Yazılı Süsleme}

Sikkeler üzerinde yer alan yazı bir taraftan sikkeyi tanımlamada kullanılırken bir taraftan da sikkenin bezenmesinde kullanılmıştır. Figürsel ve geometrik süslemelerle birlikte yazı da sikkenin süslenmesinde kendine yer bulmuştur. Ele alınan Artuklu sikkelerinde ağırlıklı olarak kûfî yazı kullanılmışken, 7 ve 8 . sırada tanıtılan örneklerde nesih karakterli yazılar kullanılmıştır.

\section{$>$ Tasvir-Burç Bilgisi}

İslami paralar üzerinde belirgin olarak desen ve motiflerin kullanılmasının yanı sıra, sikkeler üzerinde yer alan yazı ile figürlerin noktasal tekrarlardan oluşan daireler ile düz dairesel formların içine alınması, Zengi, Artuklu ve Anadolu Selçuklulara ait sikkelerde görülmektedir. İslami sikke geleneğine bakıldığında, İslam öncesi döneme tarihlenen putperestlik anlayışının tekrar hortlaması tehdidine karşı, sikkeler üzerinde resim görülmez. Artuklular bu geleneğin dişına çıkarak sikkelerde tasvire yer verdiği görülür. Zengi, Danişmentliler, Saltuklar ve Selçuklular gibi Türk Devlet ve beyliklerinde de tasvirlere yer verildiği görülmektedir (Foto. 12a, 20, 21, 22, 23, ). 


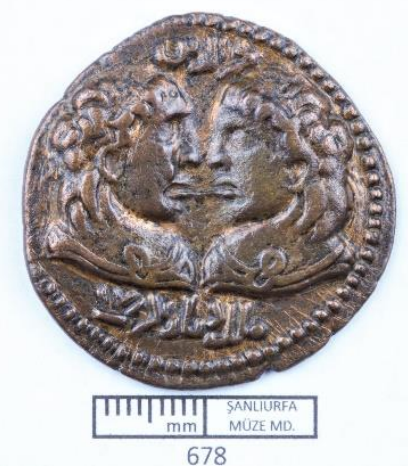

Fotoğraf 19

Artuklu Dönemi Bakır Sikke, Şanlıurfa Müzesi

Türk sanatında gerek mimari öğelerde gerekse çini, seramik ve minyatür gibi resim alanlarda figürlerin tasvir edildiği bilinmektedir. Benzer bir tasvir anlayışı sikkelerde de kendini göstermektedir. Bu dönem sikkelerinde karşımıza çıkan figür tasvirleri, astrolojik semboller, burçlar ve gezegenlere ait mistik tasarımlara dayanmaktadır. İslam öncesi Türklerde çeşitli ihtiyaçlara bağlı olarak ortaya çıan burçlar inancı, İslam sonrasında da devam etmiştir. İslami dönem sikkelerinde ve dolayısıyla Artuklulara ait sikkelerde de bunu görmek mümkündür. İkizler burcunun sembolü olan bir sikkedeki iki insan başı birbirine dönük pozisyondadır (Çayc1, 2002, s. 107). Karşılıklı iki figürün yüzleri birbirine dönük, saçları kıvırcık ve diademlidir (Foto. 19). Ok ve yayın kullanılması yay burcunu sembolize etmektedir (SpenglerSayles, 1992, s. 124). İnsan başı ve hayvan gövdesinden meydana gelen kentaurun başı geri doğru dönük, sağ elinde yay ve sol elinde okunu, ejdere dönüşen kuyruğunu hedef almaktadır (Foto. 1a). Bunun yanı sıra İslam sanatında, arslan burcu ve gezegeninin birlikteliğini betimleyen semboller, astrolojik bir ifade tarzı olarak bilinmektedir (Uykur, 2010, s. 424).

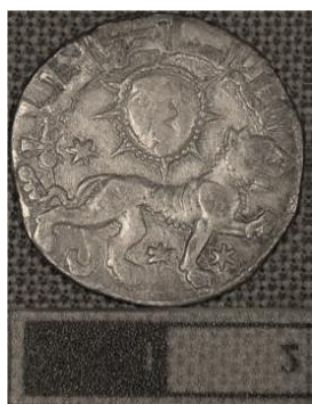

Fotoğraf 20

Aslan Figürlü Gümüş Sikke (Selçuklu Dön.)

(G. Aydoğdu'dan)

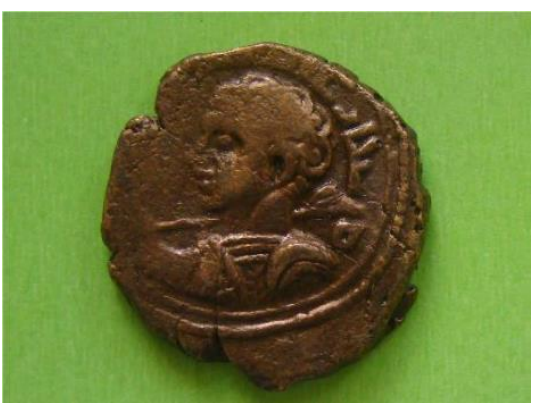

Fotoğraf 21

Hükümdar Tasviri (Zengi Dön.)

(N. Akkaya'dan)

\section{Sonuç}

Bu çalışmada, müzede Artuklu dönemine ait olarak kayıtlıyken, analizlerde Zengi dönemine ait olduğu tespit edilen bir sikke üzerinde de bir kişiye ait figürün yer aldığ1 görülmektedir (Foto. 12a-b). Zengi dönemine tarihlenen bu eserin çalışmaya dâhil edilmesinde, Artuklular ile Zengi dönemine ait olan sikkelerin benzerliklerine dikkat çekmek amaçlanmıştır. Eyyubi, Artuklu, Zengi ve Anadolu Selçuklular döneminde üretilen sikkelerdeki figürlerin benzerliklerinin yanı sıra, figür çeşitliliği bakımından da oldukça zengindir. Benzerlikler genel hatlarıyla büst şeklinde hükümdar/insan figürü, aslan/aslana binmiş hükümdar ile tahtta 
oturmuş, bağdaş kurmuş hükümdar tasvirleri olarak öne çıkmaktadır. Çalışmada ele alınan örneklerden 2 ve 6 . sırada yer alan sikkeler, süsleme programları açısından Mardin Müzesi'nde bulunan Eyyubi dönemi sikkeleriyle benzerlik göstermektedir (Foto. 22, 23).

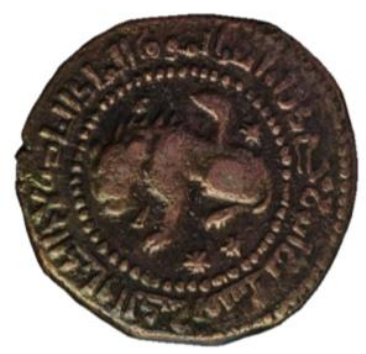

Fotoğraf 22. Aslan figürlü bakır sikke (E. Günay'dan)

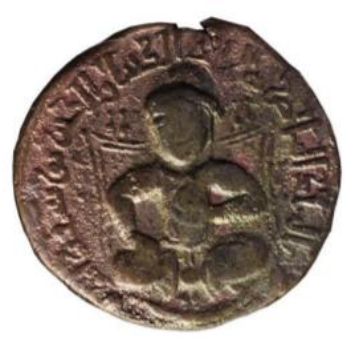

Fotoğraf 23. Hükümdar tasvirli bakır sikke (E. Günay'dan)

Eyyubi dönemine ait yukarıda gösterilen sikkelerden aslan figürlüsü dikkat çekicidir (Foto. 22). Aslan; başı dörte üç profilden verilmiş, yeleli, vücut hatları belirgin ve kuyruğu yukarı doğru sola dönük olarak tasvir edilmiştir (Günay, 2019, s. 35). Çalışmada yer alan aslan figürü ise binicisiyle birlikte gösterilmiş olması ile sola doğru haraket halinde oluşuyla diğerinden ayrilmaktadır (Foto. 2).

Eyyubi dönemine ait diğer figürlü sikkenin yüzeyinde, tahtta Türk oturuşu olarak da tabir edilen bağdaş kurmuş bir hükümdar bulunmaktadır (Foto. 23); (Günay, 2019, s. 41). Bu eserle benzerlik gösteren bir sikke, çalışmada 6. sırada gösterilmiş örnekte görülmektedir. Artuklulara ait tanımlanan sikkenin ön yüzünde, diğer eserde olduğu gibi bir siluet şeklinde tasvir edilerek, figürün sağ eli dizinin üzerindeyken sol eli ise göğsünün üzerinde bir küre tutarak resmedilmiştir. Gerek yukarda tanıtılan Eyyubi sikkeleri gerekse de müzede Artuklu dönemine atfedilen ancak Zengi sikkesi olduğu anlaşılan sikke (Örnek no. 12) ile çalışmaya dahil edilen Artuklu sikkeleri arasında doğrudan bir ilişki bulunmaktadır. Bu ilişki sikkelere uygulanan süsleme programları başta olmak üzere kullanılan yazı karakteri ile yazı içeriği gibi hususlarla kendini göstermektedir.

Sonuç olarak sikkeler içinde çıktığı topluma birkaç açıdan ışık tuttuğu anlaşılmıştır. Günlük temel ihtiyaçların giderilmesi noktasında standart bir ödeme aracı olan sikkeler, ticari işlevinin yanında kamuya ait harcamaların karşılanmasında da önemli bir işleve sahiptir. Kültürel ve maddi bir sembol niteliğine sahip olan sikkeler, aynı zamanda devletin sosyo-ekonomik ve siyasi yapısını da tasvir etmektedirler. İncelenen örneklerden de Artuklu dönemine ait anılan hususlarda bilgi verdiği, yukarıda tanıtılan örneklerin tanım ve çözümlemelerden anlaşılmıştır.

\section{Teşekkür}

Çalışmaya konu olan Artuklu Dönemine ait sikkelerin araştırılıp incelenmesinde, her türlü desteği esirgemeyen Şanlıurfa Müze Müdürlüğüne ve sorumlu personel Yusuf KOYUNCU’ya teşekkürlerimizi bildiririz.

\section{Kaynakça}

Akkaya, N. (2011). Mardin Müzesi'ndeki İslam Dönem Sikkelerinden Örnekler, (Yayınlanmamış Doktora Tezi, Selçuk Üniversitesi, Konya). Erişim adresi: https://tez.yok.gov.tr/UlusalTezMerkezi/tezSorguSonucYeni.jsp. 
Artuk, İ. ve C. (1970). İstanbul Arkeoloji Müzeleri Teşhirdeki İslami Sikkeler Kataloğu, C. I. ve II., İstanbul: YKY.

Artuk, İ. ve C. (1993). Artukoğulları Sikkeleri, İstanbul: Sümer Kitabevi, Alemdar Ofset.

Aslanapa, O. (2011). Türk Sanatı, İstanbul: Remzi Kitapevi.

Aydoğdu, G. (2012). Kahramanmaraş Müzesi'ndeki İslam Dönemi Sikkeleri (Osmanlı Dönemine Kadar), (Yayınlanmamış Doktora Tezi, Süleyman Demirel Üniversitesi, Isparta). Erişim adresi: https://tez.yok.gov.tr/UlusalTezMerkezi/tezSorguSonucYeni.jsp

Butak, B. (1947). XI. XII. XIII. Yüzyıllarda Resimli Türk Paraları, İstanbul: Pulhan Matbaası.

Çaycı, A. (2002). Anadolu Selçuklu Sanatında Gezegen ve Burç Tasvirleri, Ankara:Kültür Bakanlığı.

Çaycı, A. (2001). “Selçuklu ve Artuklu Sikkelerinde Zodiak Tasvirleri”, I. Uluslararası Selçuklu Kültür ve Medeniyeti Kongresi, Konya, s.207-218

Çaycı, A. (2001). “Artuklu Sikkelerinde Hükümdar Tasvirleri”, Uluslararası Sanat Tarihi Sempozyumu, Prof.Dr. Gönül Öney'e Armağan, İzmir, s.185-194

Günay, E. (2019). Mardin Müzesi'ndeki Eyyubi Sikkeleri, İstanbul: Hiperyayın.

Spengler, W.F.-Sayles, W.G. (1992). Turkoman Figural Bronze Coins and Their Iconography Volume I, USA.

Tekin, O. (1997). Antik Nümismatik ve Anadolu (Arkaik ve Klasik Çağlar), İstanbul: Arkeoloji ve Sanat Yayınları.

Tekin, O. (2009). "Sikke", İstanbul: İslam Ansiklopedisi, TDV, C. 37.

Uykur, R. (2017). Madenden Yansıyan Tarih, Artuklu Sikkeleri, Ankara: Atatürk Kültür Merkezi Yayınları.

Uykur, R. (2010). Artuklu Sikkelerinde Yazı ve Süsleme Kompozisyonu, (Yayınlanmamış Doktora Tezi, Gazi Üniversitesi, Sosyal Bilimler Enstitüsü, Ankara). Erişim adresi: https://tez.yok.gov.tr / Ulusal TezMerkezi/tezSorguSonucYeni.jsp

\section{Çizimler}

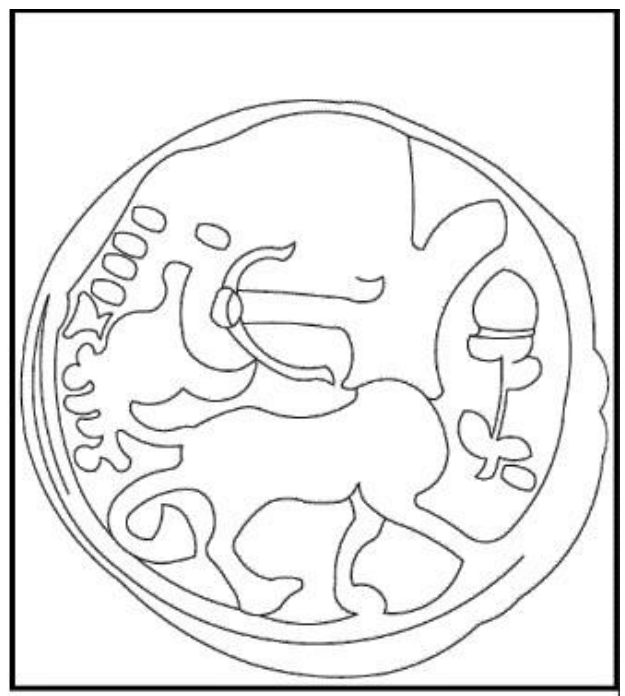

Örnek 1; Çizim 1 

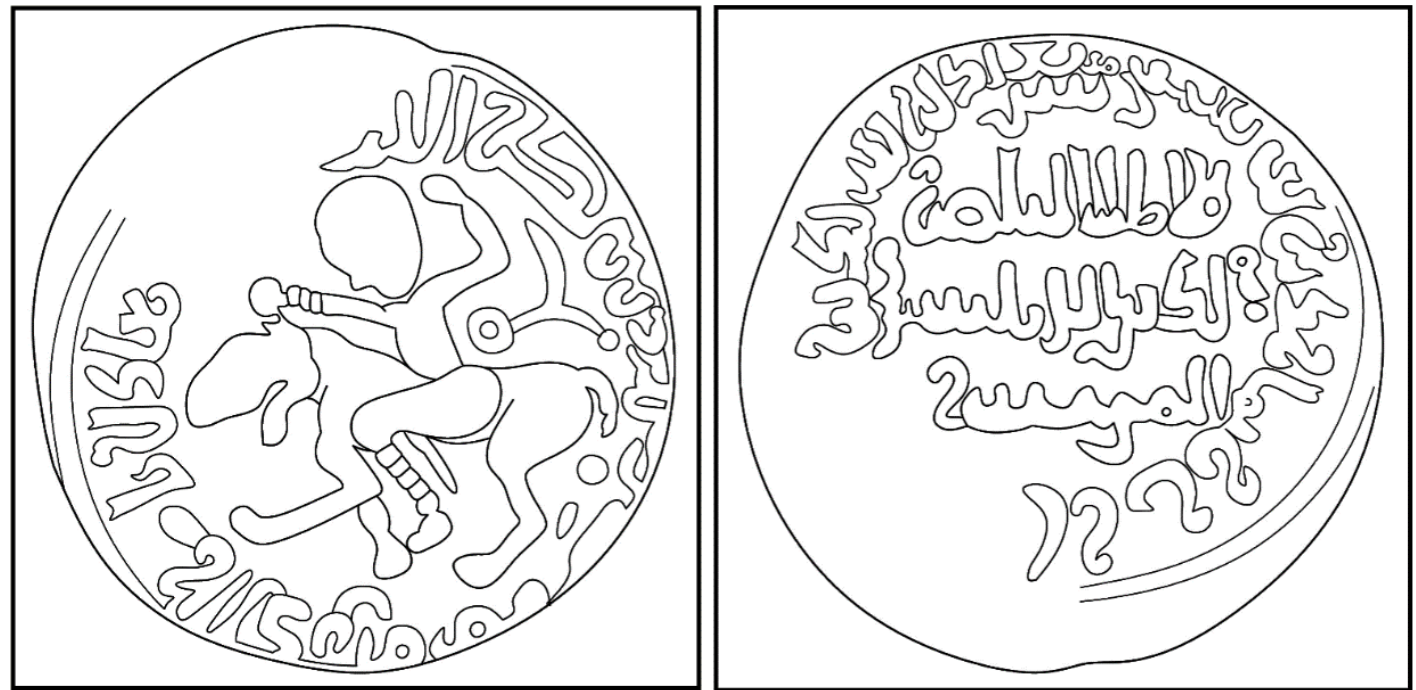

Örnek 2; Çizim 2a-b
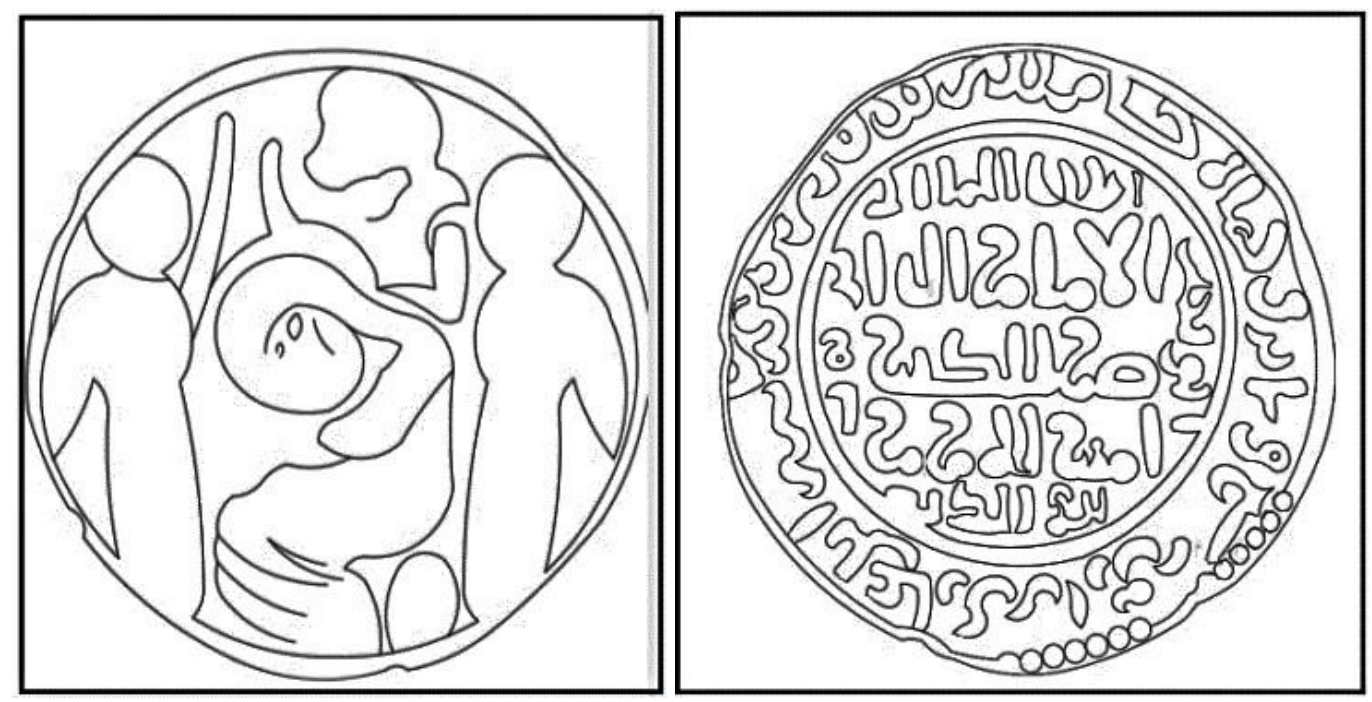

Örnek 3; Çizim 3a-b
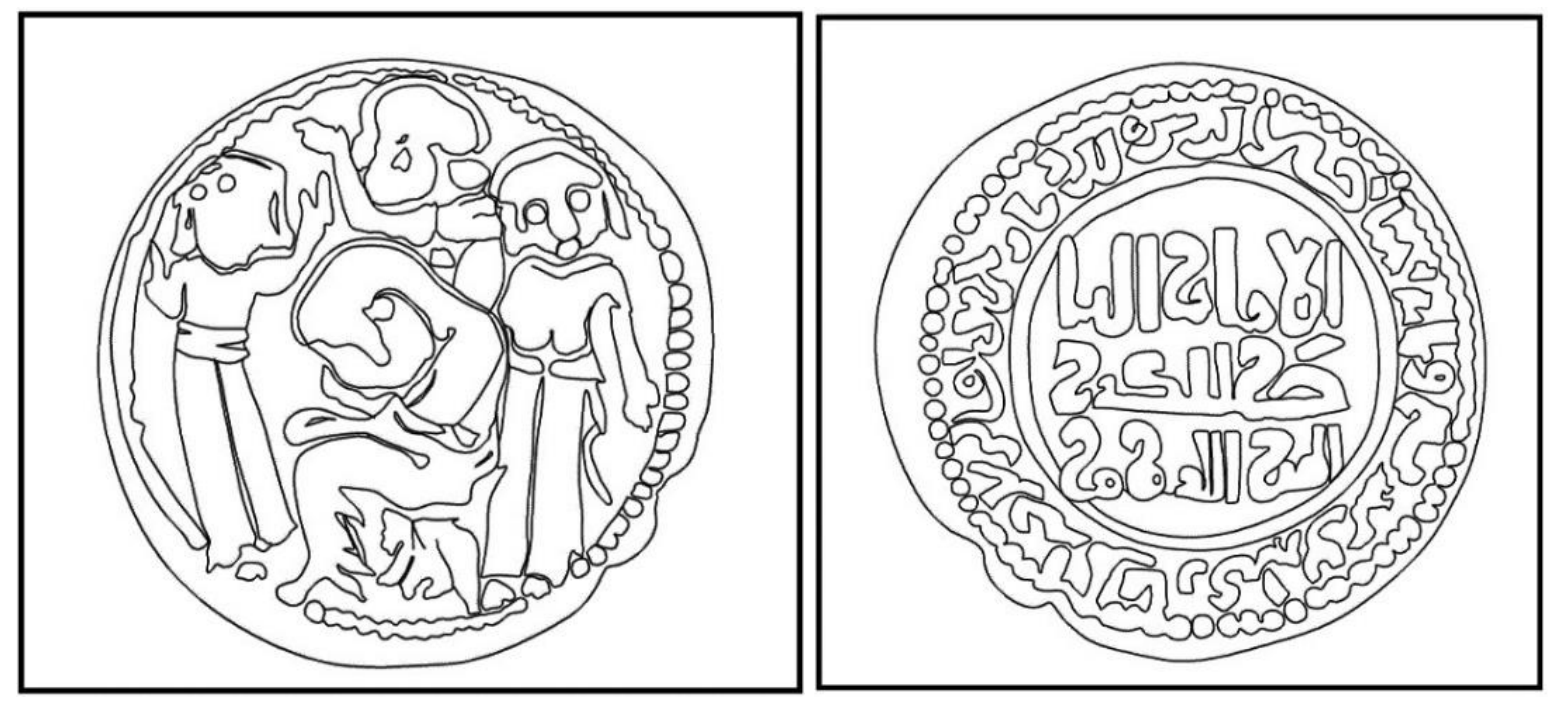

Örnek 4; Çizim 4a-b 


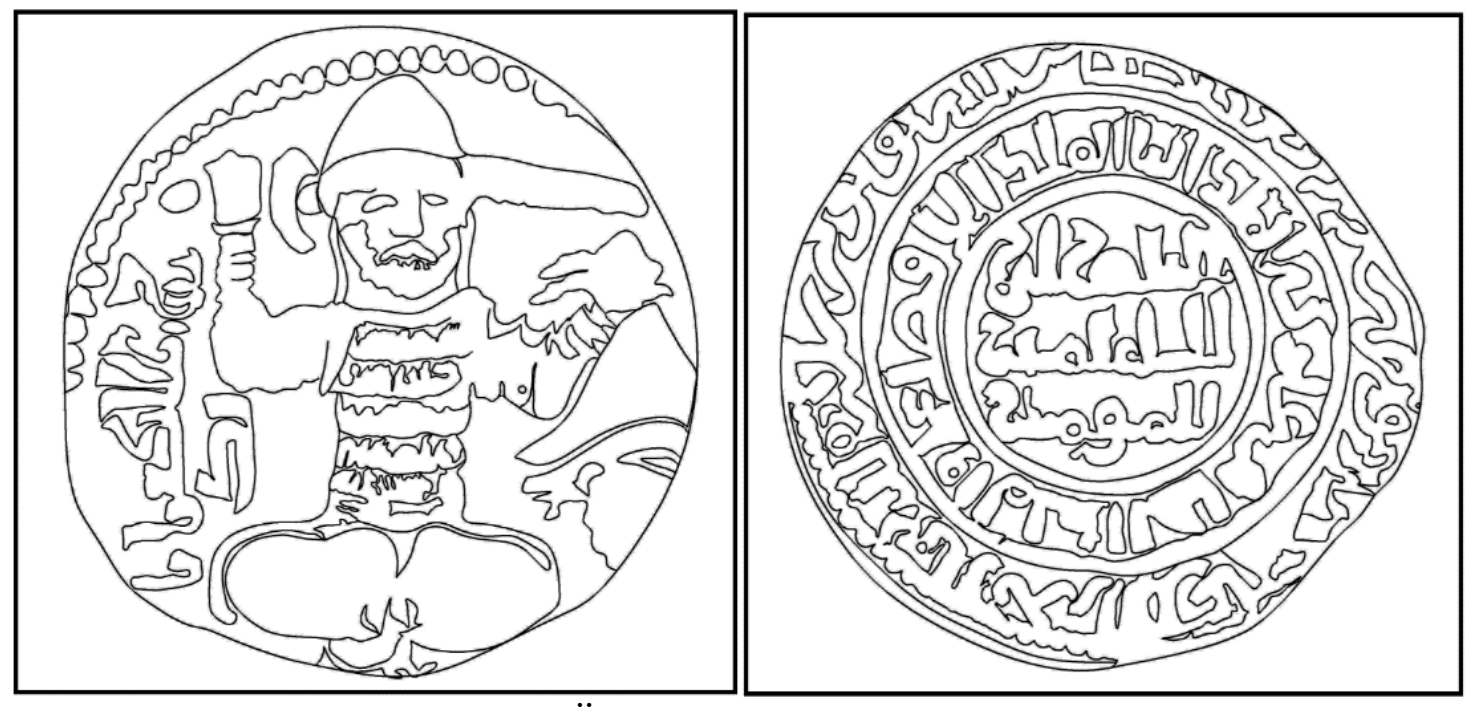

Örnek 5; Çizim 5a-b

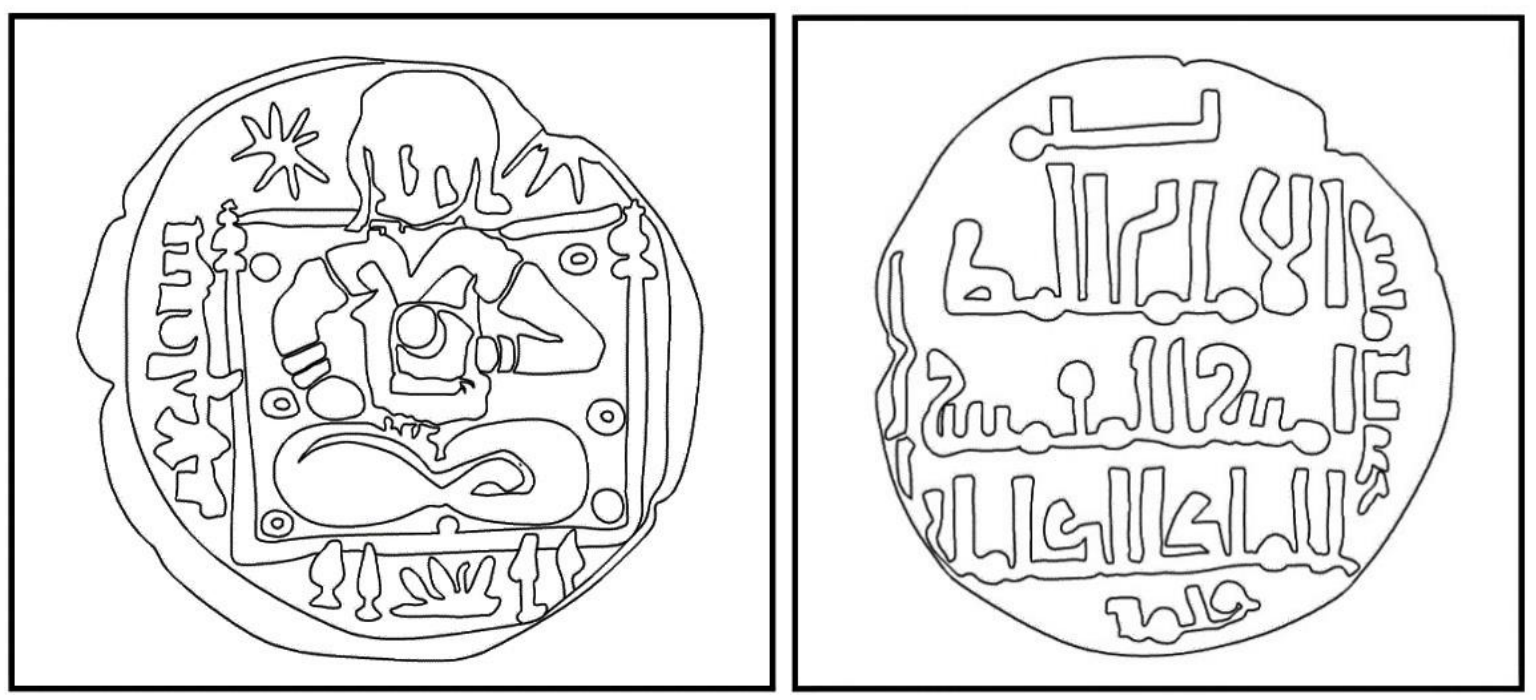

Örnek 6; Çizim 6a-b
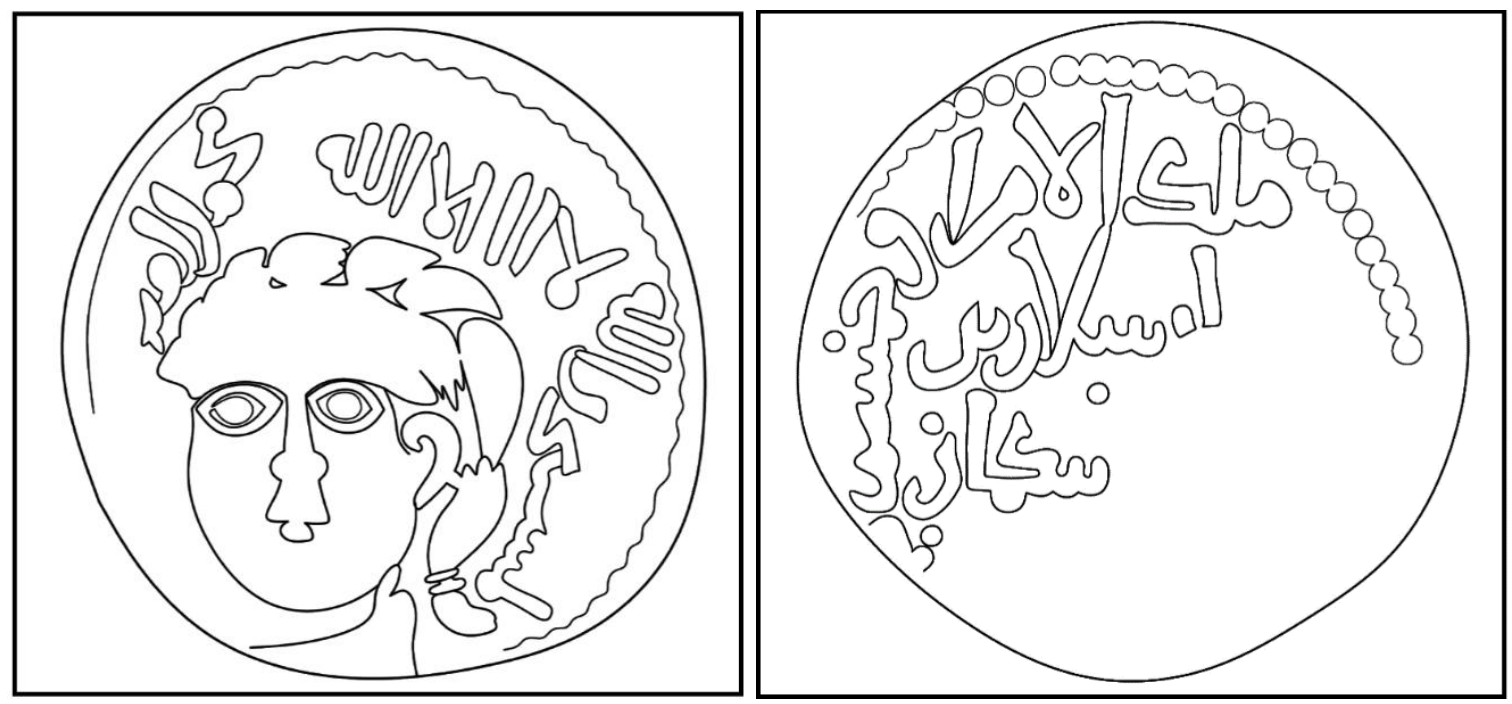

Örnek 7; Çizim 7a-b 

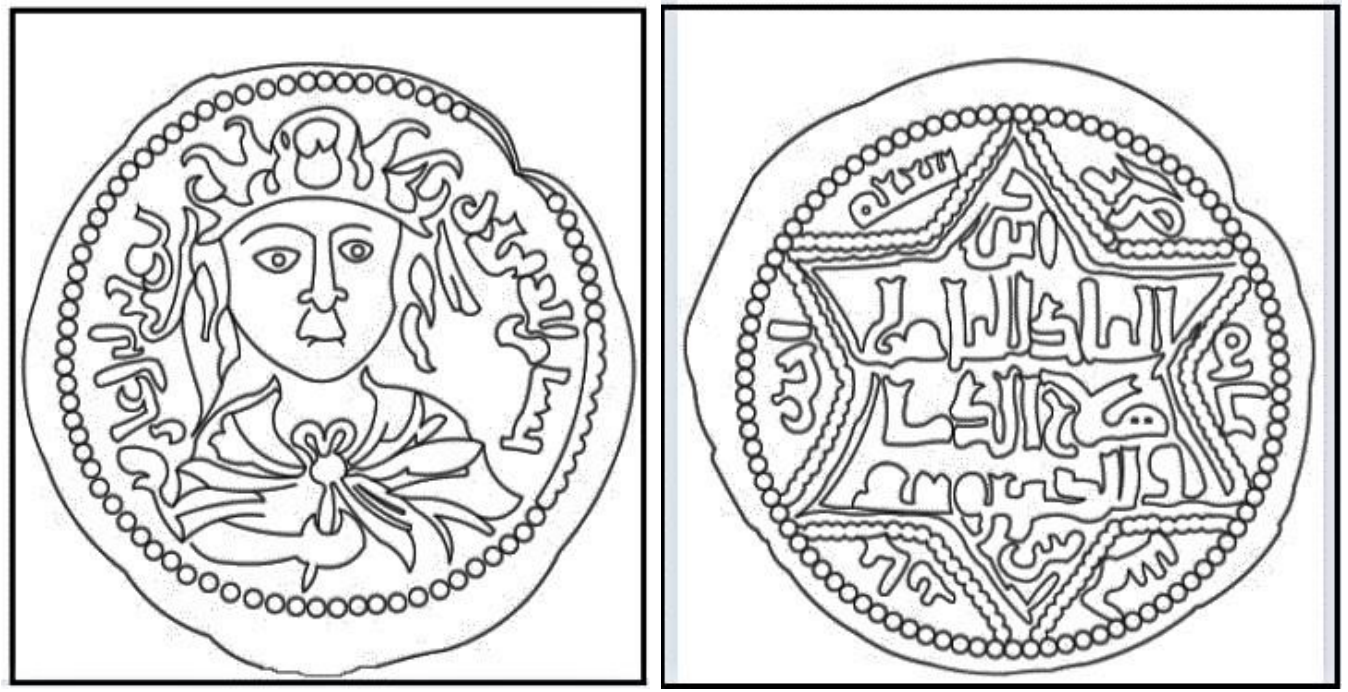

Örnek 10; Çizim 8a-b
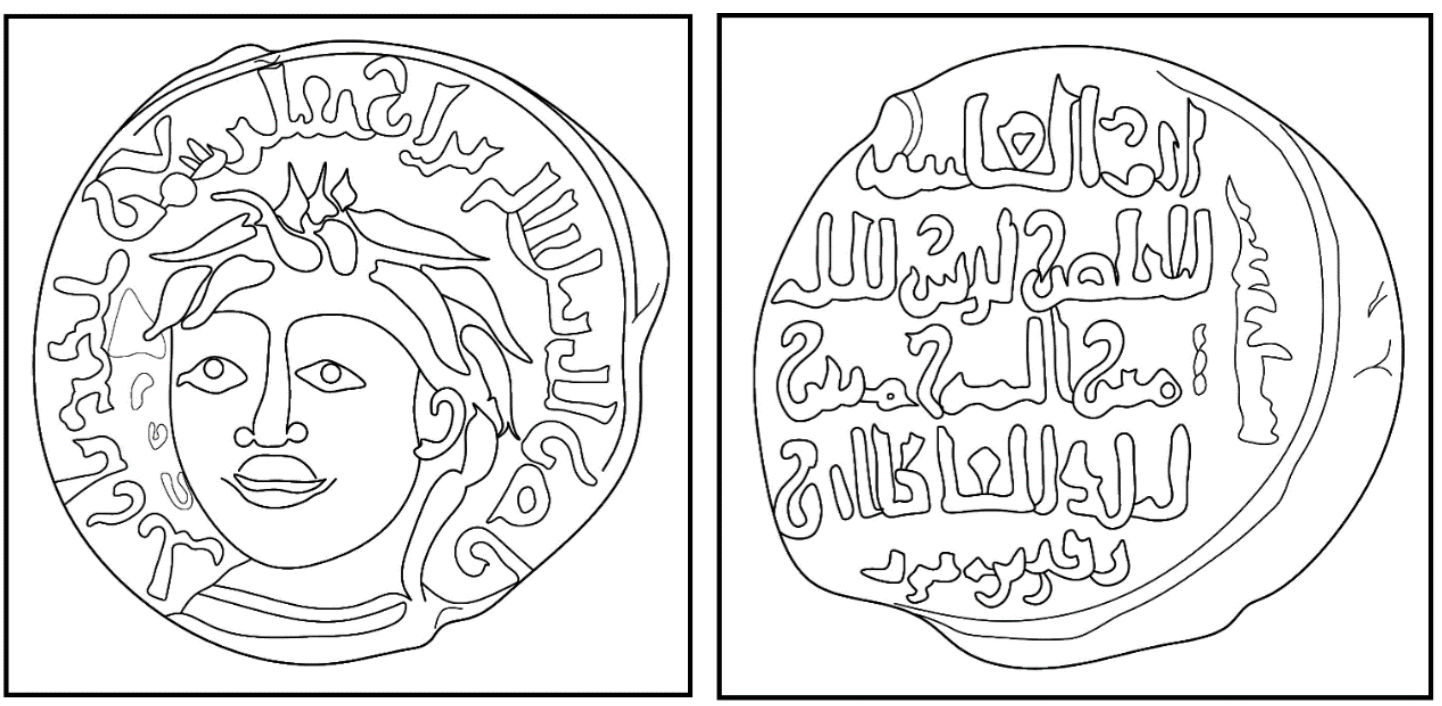

Örnek 11; Çizim 9a-b
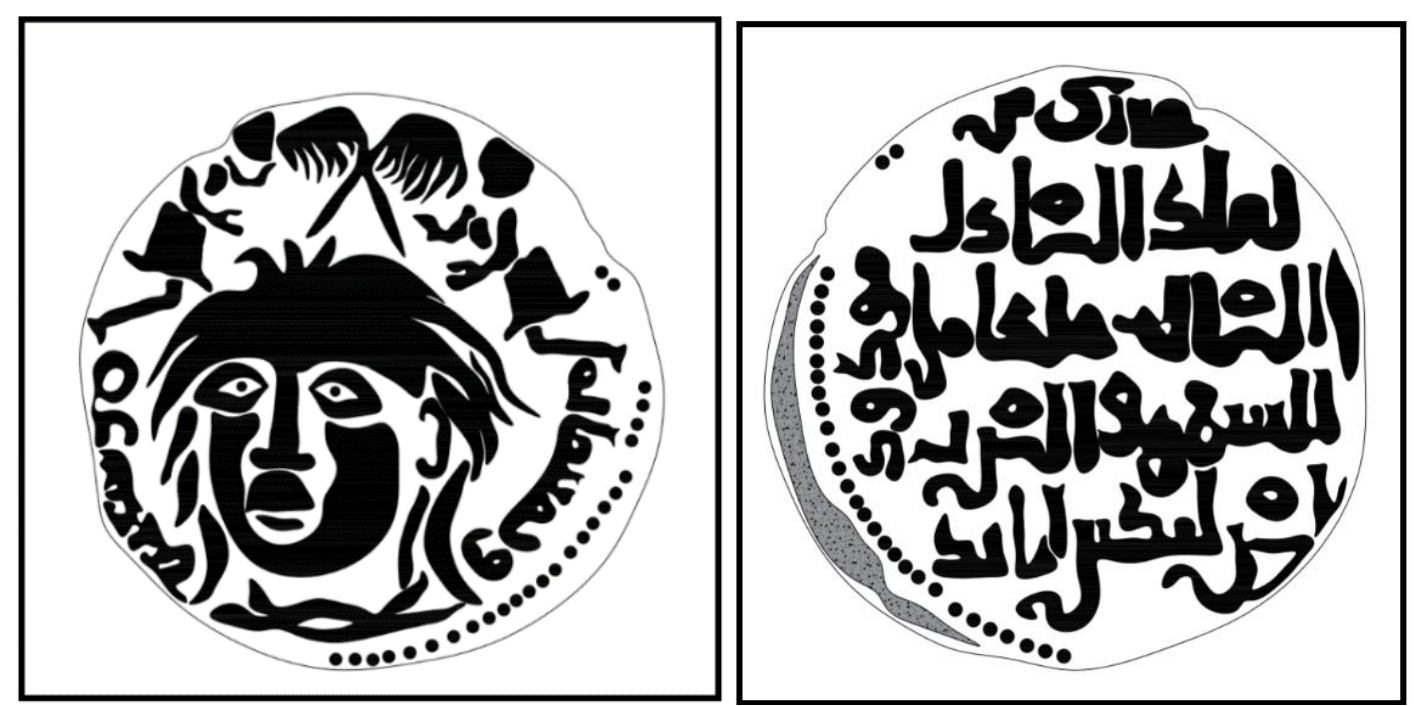

Örnek 12; Çizim 10a-b 